\title{
1.8.3 Site System Engineering FY 1997 Program Plan
}

Date Published

September 1996

Prepared for the U.S. Department of Energy Office of Environmental Restoration and

Waste Management

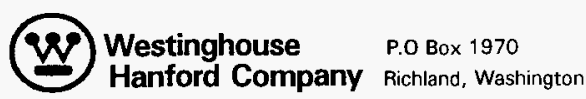

Hanford Operations and Engineering Contractor for the

U.S. Department of Energy under Contract DE-AC06-87RL10930 
LEGAL DISCLAMER

This report was prepared as an account of work sponsored by an agency of the United States Government. Neither the United States Government nor any agency thereof, nor any of their employees, nor any of their contractors, subcontractors or their employees, makes any warranty, express or implied, or assumes any legal liability or responsibility tor the accuracy, completeness, or any third party's use or the results of such use of any information, apparatus, product, or process disclosed, or represents that its use would not infringe privately owned rights. Reference herein to any specific commercial product, process, or service by trade name, trademark, manufacturer, or otherwise, does not necessarily constitute or imply its endorsement, recommendation, or favoring by the United States Government or any agency thereof or its contractors or subcontractors. The views and opinions of authors expressed herein do not necessarly state or reflect those of the United States Government or any agency thereof.

This report has been reproduced from the best available copy. Available in paper copy and microfiche.

Available to the U.S. Department of Energy and its contractors from

Office of Scientific and Technical Information

P.O. Box 62

Oak Fidge, TN 37831

(615) 576-8401

Available to the public from the U.S. Department of Commerce National Technical Information Service 5285 Port Royal Road

Springtield, VA 22161

(703) $487-4650$

Printed in the United Statea of America

DISCLM-1.CHP (1-91) 


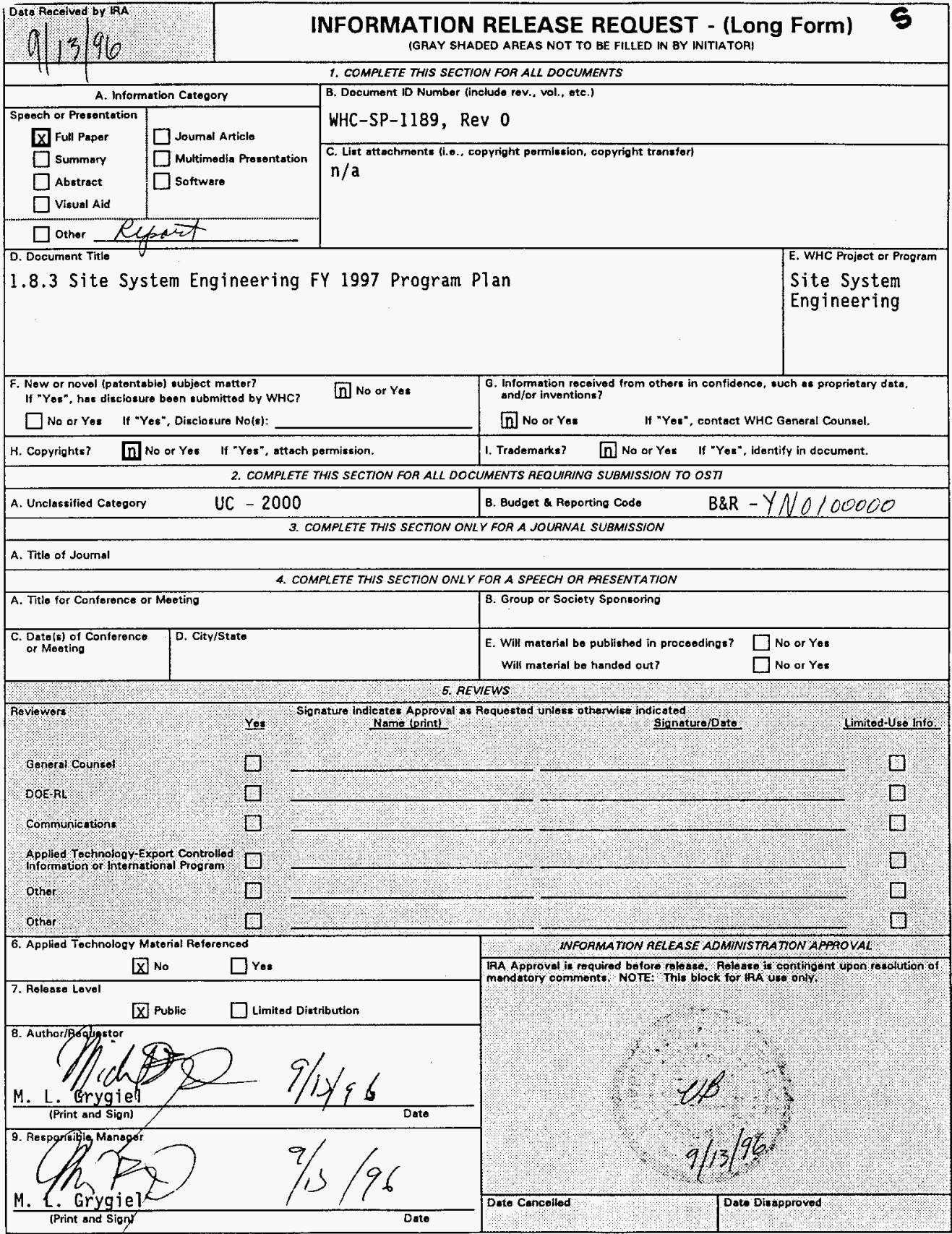


WHC-SP-1189, Rev. 0

Document ID Number

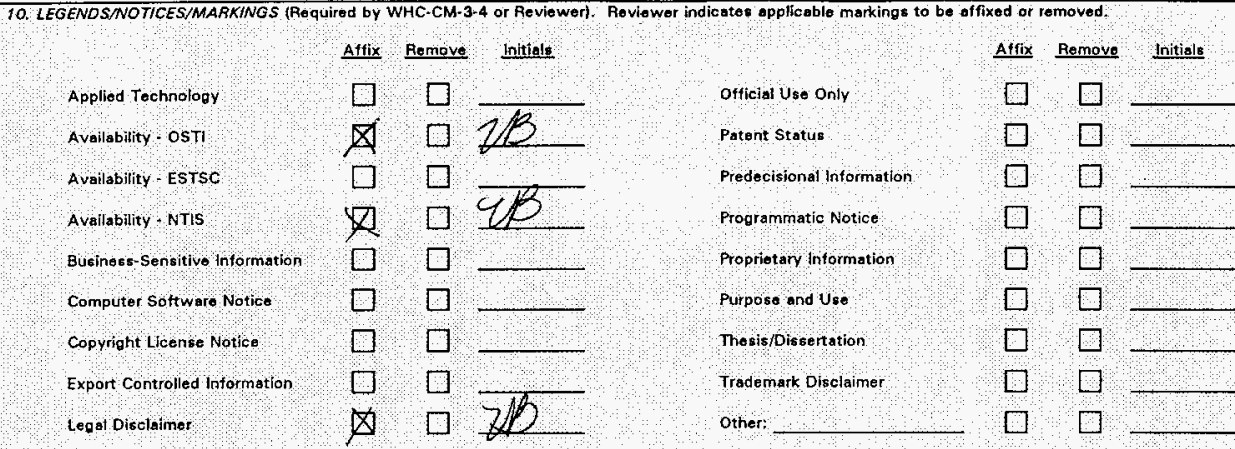

Limited Disclostirs

17. MANOATOAV COMMENTS IList only mand atory comments here All other comments shall bo made on the document and returine to the outtior:

Reviewer
(Print 2 Sign):
Date

Resolved by Author/Requestor (Print \& Sign) 


\section{TABLE OF CONTENTS}

1.0 TECHNICAL BASELINE . . . . . . . . . . . . .... 1-1

1.1 Project Mission . . . . . . . . . . . . . . . . . . . 1-1

1.2 Project End Point Targets . . . . . . . . . . . . . . . . . . 1-1

1.2.1 End Point Targets .............. 1-1

1.2.2 Technical Objectives ............. 1-2

1.2.3 Safety Objectives ............ . 1-2

1.3 Summary-Level Forecasting Data . . . . . . . . . . . . 1-2

1.3.1 Waste Type Data . . . . . . . . . . . 1-2

1.3.2 Nuclear Materials ............ . 1-3

1.3.3 Facilities (Excess, Deactivated) . . . . . 1-3

1.3.4 Infrastructure (e.g., Power. Steam, Water, Roads,

Railroad, Sanitary Waste) . . . . . . . . . 1-4

1.4 Drivers . . . . . . . . . . . . . . . . . . . . 1-4

1.4.1 Key Drivers . . . . . . . . . . . . . 1-4

1.4.2 Regulatory Drivers . . . . . . . . . . 1-4

1.5 Functional Definitions ................. . 1-5

1.6 Project Life-Cycle Requirements as defined in RLID 430.1 : 1-5 1.6.1 Management Requirements . . . . . . . . . . 1-6

1.6.2 Acquisition Requirements ......... . 1-6

1.6.3 Operations and Maintenance Requirements . . . . . 1-6

1.6.4 Disposal Requirements . . . . . . . . 1-6

1.7 Project Issues and Assumptions ............. . . 1-7

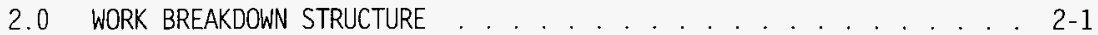

2.1 Work Breakdown Structure Hierarchy . . . . . . . . . . . . . 2-1

2.2 Work Breakdown Structure Dictionary ............ . 2-1

2.3 Work Breakdown Structure Responsibility Assignment

Matrix . . . . . . . . . . . . . . 2-7

3.0 SCHEDULE BASELINE .................... . . . . . . . . . . . . .

3.1 Program Master Baseline Schedule . . . . . . . . . . 3-1

3.2 Milestone List . . . . . . . . . . . . . . . . . . . . . . . 3-1

3.3 Milestone Description Sheets ........... 3-1 
4.0 COST BASELINE . . . . . . . . . . . . . . . . . . 4-1

4.1 $B / A$ and Cost Baseline Summaries By Year

(BCWS/PMB/Life-Cycle Cost) . . . . . . . . . . . . 4-1

4.2 Basis of Estimate . . . . . . . . . . . . . . . 4-1

4.3 Planned Staffing Profiles (Average

Full-Time Equivalents) . . . . . . . . . . . . 4-1

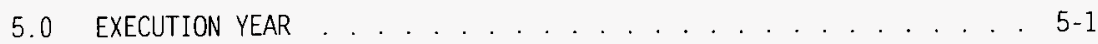

5.1 Performance Measure, Objectives, Measures, and Expectations . . . . . . . . . . . . . . 5-1

5.2 Program Performance Baseline Schedule . . . . . . . . . . . 5-1

5.3 Cost Baseline by Month . . . . . . . . . . . . . . . . . . . 5-1

5.4 Cost Element by Year . . . . . . . . . . . . . . . . 5-1

5.5 Program Funding . . . . . . . . . . . . . . . . . . . . 5-1

5.6 Project Work Scope Mapping . . . . . . . . . . . 5-1 


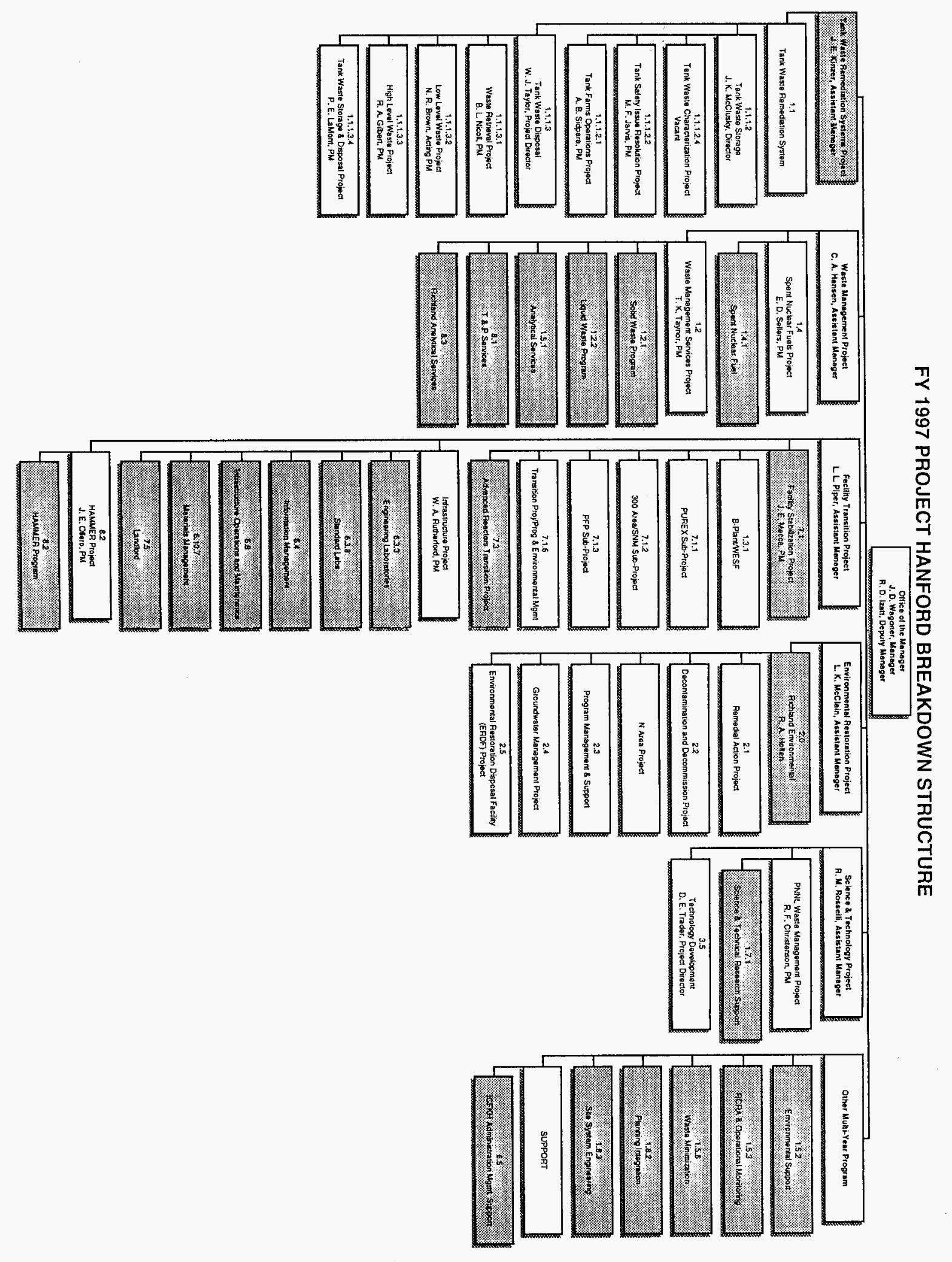




\subsubsection{SITEWIDE SYSTEM ENGINEERING PROJECT MULTI-YEAR WORK PLAN}

1.0 TECHNICAL BASELINE

The technical baseline describes the work (functions) to be accomplished and the technical standards that govern the work. The following information is provided in this section of the MYWP: Project Mission: Project End Point Targets: Sumary-Leve7 Forecasting Data (waste type. nuclear material. facility, infrastructure needs): Drivers (key mission and regulatory): Functional Definitions: Project Life Cycle Requirements; Project Issues and Assumptions.

1.1 Project Mission

This section contains a narrative description of the project scope and end result(s) or end state(s) that the project will achieve, supported by the primary project responsibilities.

This element wi11 integrate the site level technical baseline for the Hanford Cleanup mission consistent with RLPD 430.1 and RLID 430.1. . The primary activities in this element include: 1) Manage Technical Systems Integration; 2) Develop and Maintain the Hanford Site Technical Baseline; and 3) Provide the Hanford Site Technical Integration Infrastructure.

1.2 Project End Point Targets

This section identifies the significant end point targets. technical objectives and safety objectives to be achieved in accomplishing the project mission. This includes general and specific objectives. deliverables, or activities that are essential to the project mission. This information provides an overview of the activities and deliverables that are contained in the schedule section.

1.2.1 End Point Targets

This section contains the End Point Targets that are estab7ished in the Hanford Mission Direction Document. They provide the basis for the project mission and are implemented through technical requirements contained in the Hanford Site Technical Baseline. 
The MDD did not assign end point targets to the Sitewide System Engineering Project.

1.2.2 Technical Objectives

This section contains the Technical abjectives that achieve the end point targets. They are established in various Project specific documents and are implemented through technical requirements contained in the Hanford Site Technical Baseline.

- Manage technical systems integration of the Hanford Site - Develop and maintain the Hanford Site Technical Baseline - Provide the Hanford Site Technical Integration infrastructure

1.2.3 Safety objectives

This section contains the Safety Objectives that are established in the Mission Direction Document.

The MDD did not assign safety objectives to the Sitewide System Engineering Project.

1.3 Summary-Level Forecasting Data

This section contains forecast information about the project inputs and outputs during the project life cycle. The forecast information is an integral part of the technical basis for the planning, scheduling. and budgeting process.

Waste Type Data

This section contains the waste (Solid Waste. Tank Waste, Liquid Effluents. Special Case Waste) inventory and volume projection data. These data are used to track the waste through generation. transfer, receipt, storage, and disposition. The scheduling and budgeting of work for a project must reflect the plans for disposition of waste. 
The Sitewide System Engineering Project does not generate or process waste. However, the Sitewide System Engineering Project gathers this data from the other Hanford Projects and incorporates it into the Hanford Site Technical Baseline. This supports preparation of the Project MYWP Sections 1.

1.3.2 Nuclear Materials This section contains the nuclear materials (Special Nuclear Materials. Nuclear Fuel. Cesium capsules, Strontium capsules) inventory and volume projection data. These data are used to track the nuclear materials through transfer, receipt, storage, and disposition. The scheduling and budgeting of work for a project must reflect the plans for disposition of nuclear materials.

The Sitewide System Engineering Project does not generate or process Nuclear Materials. However, the Sitewide System Engineering Project gathers this data from the other Hanford Projects and incorporates it into the Hanford Site Technical Baseline. This supports preparation of the Project MYWP Sections 1.

1.3.3 Facilities (Excess, Deactivated)

This section contains the facility forecasting data (facility. deactivation, decontamination and decommissioning. and closure). The facility data are used to track the facility through acquisition, operations and maintenance, and disposal. The scheduling and budgeting of work for a project must reflect the plans for disposition of excess and deactivated facilities.

The Sitewide System Engineering Project does not acquire. operate, maintain or dispose facilities. However, the Sitewide System Engineering Project gathers facilities data from the other Hanford Projects and incorporates it into the Hanford Site Technical Baseline. This supports preparation of the Project MYWP Sections 1. 
1.3.4 Infrastructure (e.g., Power, Steam, Water, Roads, Railroad, Sanitary Waste)

This section contains the forecasting data for infrastructure support. These data are used to ensure the required

infrastructure is available when it is needed. The scheduling and budgeting of work for a project must reflect the services

(infrastructure) that are necessary to achieve the project mission.

The Sitewide System Engineering Project does not provide the site infrastructure. However, the Sitewide System Engineering Project gathers this data from the other Hanford Projects and incorporates it into the Hanford Site Technical Baseline. This supports preparation of the Project MYWP Sections 1.

1.4 Drivers

This section identifies the documents that are sources of project requirements, including Key and Regulatory Drivers.

1.4 .1

Key Drivers

This section lists the source documents that tend to drive the project mission (e.g. Mission Direction Document. Tri-Party Agreement).

\begin{tabular}{|l|l|}
\hline \multicolumn{1}{|c|}{ NAME } & \multicolumn{1}{|c|}{ TITLE } \\
\hline RLID 430.1 & Hanford Site Systems Engineering Policy \\
\hline RLPD 430.1 & System Engineering Criteria Document and Implementing Directive \\
\hline $\begin{array}{l}\text { WHC-SD-WM-SEMP-004 } \\
\text { Rev 0 }\end{array}$ & Hanford Site System Engineering Management Plan \\
\hline
\end{tabular}

1.4 .2

Regulatory Drivers

This section contains the source documents that must be followed as the Project mission is accomplished.

No additional regulatory drivers apply specifically to 1.8.3. 
1.5 Functional Definitions

This section contains the Hanford Site Technical Baseline functions that are assigned to the project. It describes the project work in terms consistent with the Hanford Site Technical Baseline.

\begin{tabular}{|l|l|}
\hline Function Number & Function Description \\
\hline 1.0 & $\begin{array}{l}\text { Manage Program: The MANAGE PROGRAM function provides al1 } \\
\text { program planning, management direction, evaluation, and } \\
\text { the management system. This function does not directly } \\
\text { contribute to the final state but provides the management } \\
\text { needed to conduct the mission. The function includes } \\
\text { specification of management policies and procedures. } \\
\text { configuration management, scheduling, allocation of a11 } \\
\text { resources, definition of performance criteria, and } \\
\text { resolution of regulatory problems. }\end{array}$ \\
\hline 2.0 & $\begin{array}{l}\text { Acquire Mission Essential Capabilities: The ACQUIRE } \\
\text { MISSION ESSENTIAL CAPABILITIES function provides al1 new } \\
\text { intellectual and physical resources. This includes } \\
\text { personnel, consultants, services, supplies, equipment, } \\
\text { construction projects, and subcontracts of all kinds. }\end{array}$ \\
\hline 3.0 & $\begin{array}{l}\text { obtain Public Acceptance: The OBTAIN PUBLIC ACCEPTANCE } \\
\text { function provides all the public interactions needed to } \\
\text { complete the mission including public relations, reviews } \\
\text { of all plans and priorities, as needed to minimize } \\
\text { potential conflicts between the stakeholder interests and } \\
\text { mission activities. }\end{array}$ \\
\hline
\end{tabular}

1.6 Project Life-Cycle Requirements as defined in RLID 430.1

This section contains the requirements for each project life cycle phase including the project management requirements. 
1.6.1 Management Requirements

This section contains the management requirements (generally key dates and project performance milestones) for the project.

\begin{tabular}{||l|l|}
\hline \multicolumn{2}{|c|}{ MANAGEMENT REQUIREMENTS } \\
\hline 1 & Manage Technical System Integration of the Hanford Site \\
\hline 2 & Continue to develop and maintain the Hanford Site Technical Baseline \\
\hline 3 & Provide the Hanford Site Technical Integration Infrastructure \\
\hline
\end{tabular}

1.6.2 Acquisition Requirements

This section contains the acquisition requirements (e.g.

Environmenta 7 Impact Statements. Resource Conservation and Recovery Act [RCRA] Permits).

\subsection{3 has no specific requirements in this area.}

1.6.3 Operations and Maintenance Requirements

This section contains the operations requirements (e.g. retrieve, treat. store and dispose of $x$ cubic meters of waste) and the maintenance requirements (e.g. availability and maintainability requirements).

\subsection{3 has no specific requirements in this area.}

1.6 .4

Disposal Requirements

This section contains the disposal requirements (e.g. essential safety systems must be identified and maintained operational during deactivation. all radionuclides must be removed or stabilized during decontamination).

1.8.3 has no specific requirements in this area. 
1.7 Project Issues and Assumptions

This section contains the issues that must be resolved by the project. These include project specific issues. as well as the site-level issues that have been assigned to the project for resolution. It also contains the assumptions that are used as a basis for the development of project plans until the issues are formally resolved with records of decision.

ASSUMPTIONS: The following assumptions have been made for this WBS element:

- Project support is provided as needed for development and maintenance of Site Wide System Engineering products and activities.

- Update existing Site SEMP will be a minor revision to the existing Site SEMP to account for new organizations and nomenclature.

- Update procedures for the Site SEMP is a minor revision to the . procedural material in the current WHC Site SEMP.

- Project Managers will support the System Requirements Review with resources and funding as needed.

- Projects are required to resolve open issues affecting their projects as assigned in the Technical Issues Management List.

- $\quad$ Support for gathering, organizing. storing, and reporting forecasting data will be provided from the Projects and PID. Without this support. this will be a minimal activity to utilize data currently residing in the Hanford Site Technical Baseline.

- The level of support for the Site Requirements Review will be minimal (e.g., less than two man months). 
2.0 WORK BREAKDOWN STRUCTURE

$2.1 \quad$ Work Breakdown Structure Hierarchy

1.8.3 - Site System Engineering

1.8.3.1 - Manage Technical Systems Integration

1.8.3.2 - Develop and Maintain Hanford Site Technical Baseline

1.8.3.3 - Provide Hanford Site Technical

Integration/Infrastructure

2.2 Work Breakdown Structure Dictionary

\section{Technical Content/Work Statement}

This element will integrate the site level technical baseline for the Hanford Cleanup mission. The primary activities in this element include: 1) Manage Technical Systems Integration; 2) Develop and Maintain the Hanford Site Technical Baseline; and 3) Provide the Hanford Site Technical Integration Infrastructure.

This WBS dictionary describes a11 of the work necessary to fully implement a complete Site Wide System Engineering Program. This WBS describes the work to follow through with the FY 96 activities, and to comply with RLPD 430.1 and RLID 430.1. to comply with the Project Hanford Management Contract Request for Proposal (RFP), and to fully implement the WHC recommended Site Wide System Engineering program. Activities that have been identified as "stretch" goals. and are not funded in FY 97, are shaded.

The Site Technical Integration path forward during FY 97 will evolve as Mission Description Document content and the role of the integrating contractor are finalized. This evolution may result in additions, deletions, or adjustments to the activities described in this dictionary. These will be handled through baseline change requests, as necessary. 


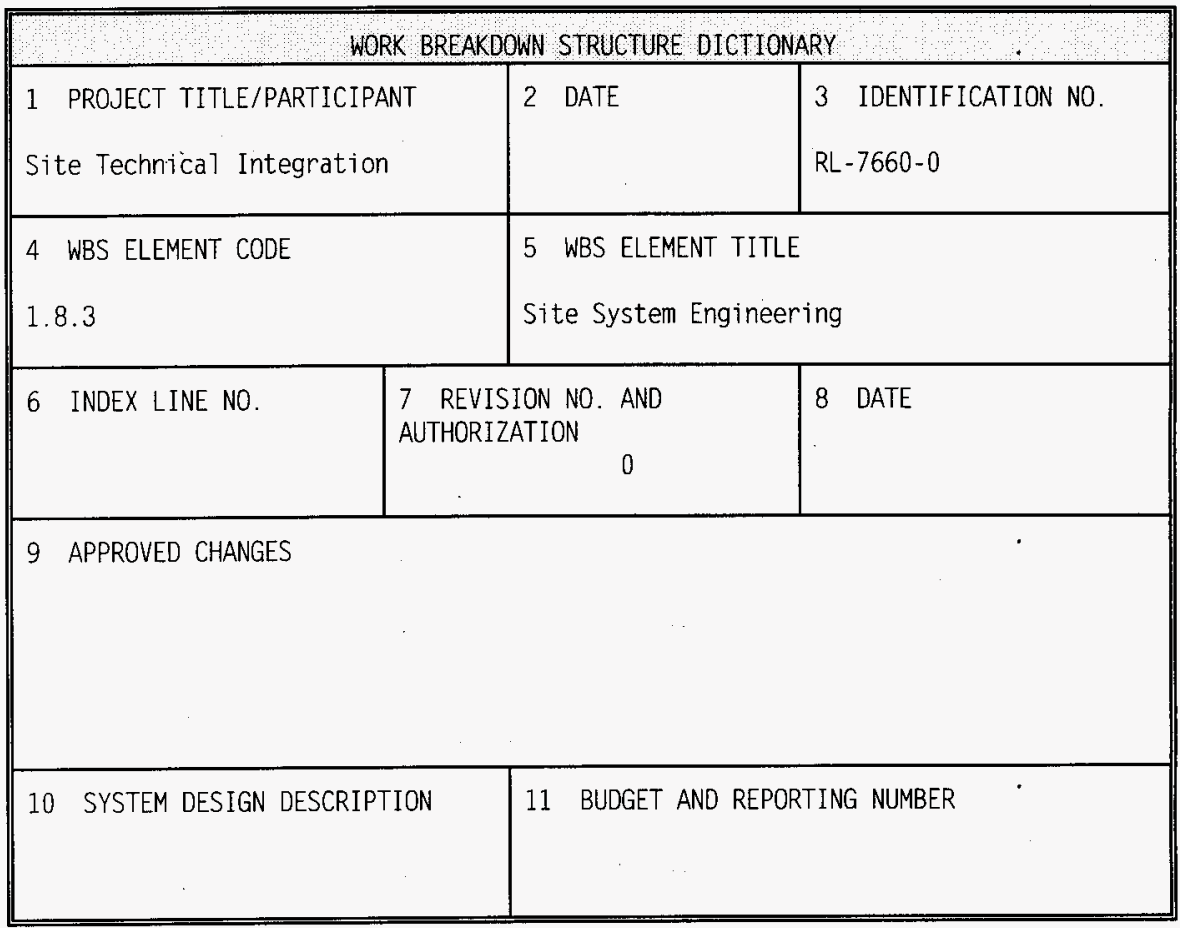


1.8.3.1 Manage Technical Systems Integration: This element manages the Technical Integration effort:

1.8.3.1 TASKS FUNDED FOR FY 97

Direct the Technical Integration for the Hanford Site

Conduct Site Wide System Engineering Integration Group (SWSEIG) meetings and manage resulting actions (RLID 2.5)

Identify and track site level issues (RLID 2.4.2)

Coordinate activities to identify and resolve open issues identified

as part of the technical baseline development and maintenance

Establish and support ad hoc issue resolution teams (RLID 2.4.2)

Work with Projects to resolve Site Level interface issues

Provide effective risk management for the site technical baseline Complete risk analyses and assessments

Support DOE interfaces with the Defense Nuclear Facilities Safety Board and National Academy of Sciences

Monitor and report on cost. schedule and technical performance for WBS element 1.8 .3

Develop the annual MYWP for WBS element 1.8 .3 
1.8.3.2 Develop and Maintain Hanford Site Technical Baseline: This element develops and maintains the Hanford Cleanup Technical Baseline (HSTB) to a level sufficient to support credible integrated technical planning of the Project Hanford Projects and Sub-Projects.

\begin{tabular}{|l||}
\hline 1.8.3.2 TASKS FUNDED FOR FY 97 \\
\hline Continue Super ICD development (submit for review and approval) (RLID \\
2.4.1) \\
\hline Perform System Engineering Analysis \\
Perform Site Systems Analyses to validate HSTB (complete primary \\
streams and initiate secondary streams) (RLID 2.3.1) \\
Support project level planning based on HSTB data \\
Issue Project Technical Baseline Sections (Sections 1) of Multi-Year- \\
Work-Plans for select Project Hanford Projects and Sub-Projects (RLID \\
2.4.1. Fig. 2, and 2.2) \\
\hline Maintain RDD-100 capability to support the activities above including data \\
entry, report preparation and license maintenance; \\
- Integration of Project RDD-100 files \\
Ad hoc report writing \\
Gather, organize, store, and report forecasting data to support Project \\
MYWPs development(Waste. materials. facilities. infrastructure) (RLID \\
2.4.1. 2.2) \\
Provide integrated waste stream data (waste, nuclear materials, and \\
facilities) tracked to the intra-project level for development of \\
technical and financial plans. \\
Hanford Site Cleanup Specification review and approval (RLID 2.4.1) \\
Produce the documents required for the SRR: \\
Coordinate support for the SRR: \\
Define entrance and exit criteria \\
- Identify participants \\
- Logistical support (meeting rooms, recorders etc.) \\
- Document distribution 30 days in advance \\
- Physical oreview with reviewers \\
-
\end{tabular}

1.8.3.3 Provide Hanford Site Technical Integration Infrastructure: This element provides the necessary infrastructure to enable system engineering and systems management to be successfut. 


\begin{tabular}{|c|}
\hline 1.8.3.3 TASKS FUNDED FOR FY 97 \\
\hline $\begin{array}{l}\text { Maintain the existing Hanford Site SEMP } \\
\text { Provide informational briefings to key Project personne? on Sitewide } \\
\text { System Engineering process }\end{array}$ \\
\hline $\begin{array}{l}\text { Provide formal configuration management for the technical baseline } \\
\text { information }\end{array}$ \\
\hline $\begin{array}{l}\text { Implement a system engineering process (SEMP) } \\
\text { - Update the procedural information in the existing Site SEMP through } \\
\text { the Sitewide System Engineering Integration Group } \\
\text { Continue to develop and maintain the Hanford Site Technical Baseline } \\
\text { consistent with RLPD } 430 \text { I and RLID } 430 \text { I }\end{array}$ \\
\hline $\begin{array}{l}\text { Administer HSTB (RDD-100) } \\
\text { - } \quad \text { Pay RDD-100 license fee } \\
\text { Upgrade to current RDD-100 version } \\
\text { - } \quad \text { Provide system backups }\end{array}$ \\
\hline
\end{tabular}




\subsubsection{STRETCH GOALS NOT FUNDED FOR FY 97}

Provide integrated information management system related to site technica] baseline and forecasting datả

Procure and deploy a comprehensive set of System Engineering computer based tools:

- Interface with the Chief Information office to define the Technical Integration inforiation needs

- Projects/Services are required to be able to interface electronically with the SWSE database for transfer and revision of data (RLID Attachinent 0 ) 


\subsection{Work Breakdown Structure Responsibility Assignment Matrix}

Work Breakdown Structure Index and Programmatic Responsibility Assignnent Matrix

\begin{tabular}{|c|c|c|c|c|c|}
\hline $\begin{array}{l}\text { PROGRAM } \\
\text { ELEMENT } \\
\end{array}$ & ACTIVITY & $\begin{array}{c}\text { COST } \\
\text { ACCOUNT } \\
\end{array}$ & TITLE & $\begin{array}{c}\text { RESPONSIBLE } \\
\text { MANAGER }\end{array}$ & $\begin{array}{l}\text { RESPONSIBLE } \\
\text { ORGANIZATION } \\
\end{array}$ \\
\hline 1.8 .3 .1 & & Y2001 & $\begin{array}{l}\text { Manage Technical Site } \\
\text { Integration }\end{array}$ & $\begin{array}{l}\text { M. L. } \\
\text { Grygiel }\end{array}$ & $\begin{array}{l}\text { Site } \\
\text { Technical } \\
\text { Integration } \\
\end{array}$ \\
\hline 1.8 .3 .2 & & $\gamma 2002$ & $\begin{array}{l}\text { Develop and Maintain the } \\
\text { Hanford Site Technical } \\
\text { Baseline }\end{array}$ & P. Baynes & $\begin{array}{l}\text { Site } \\
\text { Technical } \\
\text { Integration }\end{array}$ \\
\hline 1.8 .3 .3 & & Y2003 & $\begin{array}{l}\text { Provide Technical Site } \\
\text { Integration } \\
\text { Infrastructure }\end{array}$ & P. Baynes & $\begin{array}{l}\text { Site } \\
\text { Technical } \\
\text { Integration }\end{array}$ \\
\hline & & & & & \\
\hline & & & & & \\
\hline & & & & & \\
\hline & & & & & \\
\hline & & & & & \\
\hline & & & & & \\
\hline & & & & & \\
\hline & & & & & \\
\hline & & & & & \\
\hline & & & & & \\
\hline & & & & & \\
\hline & & & & & \\
\hline & & & & & \\
\hline & & & & & \\
\hline & & & & & \\
\hline & & & & & \\
\hline
\end{tabular}


This page intentiona17y left blank. 
3.0

\section{SCHEDULE BASELINE}

3.1

3.2

3.3

Program Master Baseline Schedule

Milestone List

Milestone Description Sheets 
3.1 Program Master Baseline Schedule 


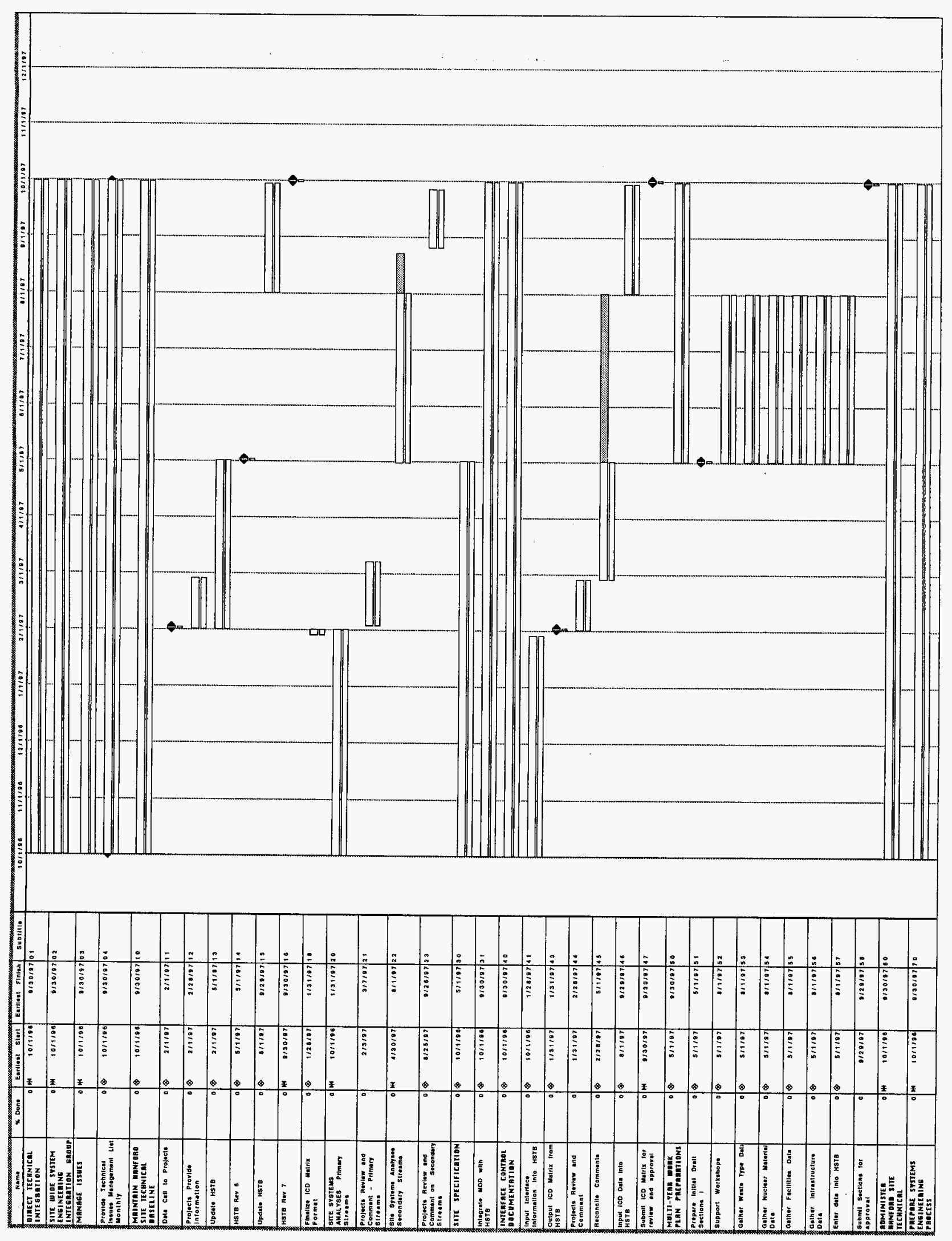




\begin{tabular}{|l|l|l|l|}
\hline \begin{tabular}{c}
\hline \\
\hline $\begin{array}{c}\text { Milestone } \\
\text { Type* }\end{array}$
\end{tabular} & $\begin{array}{c}\text { Control } \\
\text { Number }\end{array}$ & \multicolumn{1}{|c|}{ MILESTONE LIST } \\
\hline Milestone Description & $\begin{array}{c}\text { Milestone } \\
\text { Completion } \\
\text { Date }\end{array}$ \\
\hline Contractor & TSI-97-001 & Monthly Issues Management List & Sept 30, 1997 \\
\hline DOE-RL & TSI-97-002 & Project MYWP Sections 1 for Approval & Sept 29, 1997 \\
\hline DOE-RL & TSI-97-003 & Super ICD Matrix Draft for Approval & Sept 29. 1997 \\
\hline Contractor & TSI-97-004 & Hanford Site Technical Basel ine Rev. 6 & May 1, 1997 \\
\hline Contractor & TSI-97-005 & Hanford Site Technical Baseline, Rev 7 & Sept 30, 1997 \\
\hline & & & \\
\hline & & & \\
\hline & & & \\
\hline & & & \\
\hline & & & \\
\hline & & & \\
\hline & & & \\
\hline
\end{tabular}

* TPA, HQ, RL. FO, and selected contractor milestones

* On Tri-Party Agreement Milestones, also designate if they are HQ, RL 


\begin{tabular}{|c|c|c|c|}
\hline \multicolumn{4}{|c|}{$\begin{array}{l}\text { Westinghouse Hanford Company } \\
\text { MILESTONE DESCRIPTION SHEET }\end{array}$} \\
\hline \multicolumn{3}{|c|}{ Title: Monthly Issues Management List } & Date: \\
\hline \multicolumn{3}{|c|}{ Assigned To: M.L. Grygiel } & $\mathrm{CIN}:$ \\
\hline \multicolumn{3}{|c|}{ Program WBS Designator: 1.8 .3} & Due Date: Sep 30,97 \\
\hline \multicolumn{3}{|c|}{ Control Number: TSI-97-001 } & Rev: 0 \\
\hline $\begin{array}{l}\text { MILESTONE TYPE: } \\
\text { DOE-HQ } \\
\text {-DOE-RL } \\
\text { X]CONTRACTOR }\end{array}$ & $\begin{array}{l}\text { DIVISION: } \\
\text { _State } \\
\text { _Federal } \\
\text { [X] DOE } \\
\text { _RCRA } \\
\text { _TPA Number }\end{array}$ & $\begin{array}{l}\text { DELIVERABLE: } \\
\text { [X]Report } \\
\text { _Letter } \\
\text { _Drawings } \\
\text { _Other (specify) }\end{array}$ & \begin{tabular}{l}
\multicolumn{1}{c}{ ADDRESS TO: } \\
DOE-HQ \\
[X]DOE-RL \\
[X]Other (WHC Programs)
\end{tabular} \\
\hline \multicolumn{4}{|c|}{$\begin{array}{l}\text { Milestone Description: Issue management is an important task in the Site Wide System Engineering (SWSE) activities. } \\
\text { The cleanup mission at Hanford is very large and complex and there are a number of obstacles that prevent Hanford from } \\
\text { accomplishing the mission. These obstacles, called issues, cut across Hanford Projects and Services as well as other DOE } \\
\text { sites. Whether the issues are simple or complex, there must be a consistent and systematic process for resolving them. The } \\
\text { approach that will be used by the Site Wide System Engineering Integration Group (SWSEIG) to track site level issues is } \\
\text { described in the Site System Engineering Management Plan. } \\
\text { The Sitewide Technical lssue Management List (TIML) will be maintained as part of the Hanford Site Technical Baseline } \\
\text { Database. The list will be printed from the database on a monthly basis. The HSTB is maintained under configuration } \\
\text { control in accordance with the guiding procedure. It is updated by Technical Systems Integration (TSI) as issues are } \\
\text { added, changed, or completed. TSI will maintain the TIML at the site and Project interface levels. } \\
\text { The TIML is a matrix (table) that lists all the current issues and shows the status of each issue. The matrix includes } \\
\text { information on the priority (impacts), champion, owner, due date and status of the issues. }\end{array}$} \\
\hline \multicolumn{4}{|c|}{$\begin{array}{l}\text { Description of what constitutes completion of this milestone: WHC will provide the Hanford Site Technical Issues } \\
\text { Management List to RL each month, by the second Friday of the month. }\end{array}$} \\
\hline \multicolumn{4}{|c|}{ Milestone Description Approva! } \\
\hline M.L. Grygiel & Cost Account Manager Date & C. Edwards & Program/Project Manager Date \\
\hline P.A. Baynes & ram Element Manager Date & & DOE Program Manager Date \\
\hline \multicolumn{4}{|c|}{ Milestone Completion Acceptance } \\
\hline P.A. Baynes & ram Element Manager Date & & DOE Program Manager Date \\
\hline
\end{tabular}




\begin{tabular}{|c|c|c|c|}
\hline \multicolumn{4}{|c|}{$\begin{array}{l}\text { Westinghouse Hanford Company } \\
\text { MILESTONE DESCRIPTION SHEET }\end{array}$} \\
\hline \multicolumn{3}{|c|}{ Title: Project MYWP Sections 1} & Date: \\
\hline \multicolumn{3}{|c|}{ Assigned To: M.L. Grygiel } & $\mathrm{CIN}:$ \\
\hline \multicolumn{3}{|c|}{ Program WBS Designator: 1.8 .3} & Due Date: Sep 29,97 \\
\hline \multicolumn{3}{|c|}{ Control Number: TSI-97-002 } & Rev: 0 \\
\hline $\begin{array}{l}\text { MILESTONE TYPE: } \\
\text { DOE-HQ } \\
\text { [X] DOE-RL } \\
\text { CONTRACTOR }\end{array}$ & $\begin{array}{l}\quad \text { DIVISION: } \\
\text { State } \\
\text { _Federal } \\
\text { [X] DOE } \\
\text { _RCRA } \\
\text { _TPA Number }\end{array}$ & $\begin{array}{l}\text { DELIVERABLE: } \\
\text { [X]Report } \\
\text { _Letter } \\
\text { _Drawings } \\
\text { _Other (specify) }\end{array}$ & \begin{tabular}{l}
\multicolumn{1}{c}{ ADDRESS TO: } \\
DOE-HQ \\
[X]DOE-RL \\
[X]Other (WHC Programs)
\end{tabular} \\
\hline \multicolumn{4}{|c|}{$\begin{array}{l}\text { Milestone Description: The Hanford Site is managed through a series of Multi-Year-Work-Plans (MYWPs). The } \\
\text { MYWPs have } 5 \text { Sections: 1) Technical Baseline; 2) WBS Definitions; 3) Schedule Baseline 4) Cost Baseline; 5) } \\
\text { Execution Year Description. The Hanford Site Technical Baseline Database will be used as the source for Project level } \\
\text { MYWP Sections 1. This will ensure the technical basis for the Projects is consistent and integrated. } \\
\text { Section } 1 \text { contains the following type of information: } \\
\text { Project Mission } \\
\text { Project Objectives (End Point Targets) } \\
\text { Forecasting Data (Waste, Materials, Facilities, Infrastructure) } \\
\text { Drivers } \\
\text { Functional Definitions } \\
\text { Life Cycle Requirements } \\
\text { Issues and assumptions }\end{array}$} \\
\hline \multicolumn{4}{|c|}{$\begin{array}{l}\text { Description of what constitutes completion of this milestone: Sections } 1 \text { of MYWPs consistent with the Project } \\
\text { Hanford Breakdown Structure will be provided to the Projects. }\end{array}$} \\
\hline \multicolumn{4}{|c|}{ Milestone Description Ápproval } \\
\hline \multicolumn{2}{|r|}{ Cost Account Manager Date } & C. Edwards & Program/Project Manager Date \\
\hline \multicolumn{2}{|c|}{ Program Element Manager Date } & S. H. Wisness & DOE Program Manager Date \\
\hline \multicolumn{4}{|c|}{ Milestone Completion Acceptance } \\
\hline P.A. Baynes & ram Element Manager Date & S. H. Wisness & DOE Program Manager Date \\
\hline
\end{tabular}




\begin{tabular}{|c|c|c|c|}
\hline \multicolumn{4}{|c|}{$\begin{array}{l}\text { Westinghouse Hanford Company } \\
\text { MILESTONE DESCRIPTION SHEET }\end{array}$} \\
\hline \multicolumn{3}{|c|}{ Title: Super ICD Matrix Draft for Approval } & Date: \\
\hline \multicolumn{3}{|c|}{ Assigned To: M.L. Grygiel } & CIN: \\
\hline \multicolumn{3}{|c|}{ Program WBS Designator: 1.8 .3} & Due Date: Sep 29,97 \\
\hline \multicolumn{3}{|c|}{ Control Number: TSI-97-003 } & Rev: 0 \\
\hline $\begin{array}{l}\text { MILESTONE TYPE: } \\
\text { DOE-HQ } \\
\text { [X]DOE-RL } \\
\text { _CONTRACTOR }\end{array}$ & $\begin{array}{l}\quad \text { DIVISION: } \\
\text { State } \\
\text {-Federal } \\
{[\text { X] DOE }} \\
\text { RCRA } \\
\text { TPA Number }\end{array}$ & $\begin{array}{l}\text { DELIVERABLE: } \\
\text { [X]Report } \\
\text {-Letter } \\
\text {-Drawings } \\
\text { _Other (specify) }\end{array}$ & $\begin{array}{l}\text { ADDRESS TO: } \\
\text { DOE-HQ } \\
\text { [X]DOE-RL } \\
\text { [X]Other (WHC Programs) }\end{array}$ \\
\hline \multicolumn{4}{|c|}{$\begin{array}{l}\text { Milestone Description: The Super ICD is a management tool and framework for identifying and managing interfaces for } \\
\text { Project Hanford. It is a Site level index of functional interfaces (data elements) as defined in the Hanford Site Technical } \\
\text { Baseline (HSTB) and it provides a matrix of data elements between projects for the life cycle of the Hanford Cleanup } \\
\text { Mission. The matrix shows where Memorandums's of Understanding are required between Projects. } \\
\text { The Super ICD will contain the following: Introduction, definition of terms, Hanford Projects } \mathrm{N}^{2} \text { Diagrams, and Data } \\
\text { Element Interface information. A further description of the Super ICD can be found in the Site System Engineering } \\
\text { Management Plan. } \\
\text { Technical Systems Integration (TSI) will generate the tables of information for the Super ICD from the HSTB database. } \\
\text { The Project representatives are responsible for providing the requested information, reviewing the HSTB outputs, and } \\
\text { maintaining the information current via change control. }\end{array}$} \\
\hline \multicolumn{4}{|c|}{$\begin{array}{l}\text { Description of what constitutes completion of this milestone: A draft of the Super ICD Matrix that has been reviewed } \\
\text { by the Project representatives to the Site Wide System Engineering Integration Group will be submitted to RL for review } \\
\text { and approval. }\end{array}$} \\
\hline \multicolumn{4}{|c|}{ Milestone Description Approval } \\
\hline \multicolumn{2}{|r|}{ Cost Account Manager Date } & C. Edwards & Program/Project Manager Date \\
\hline \multicolumn{2}{|c|}{ Program Element Manager Date } & S. H. Wisness & DOE Program Manager Date \\
\hline \multicolumn{4}{|c|}{ Milestone Completion Acceptance } \\
\hline P.A. Baynes & am Element Manager Date & S. H. Wisness & DOE Program Manager Date \\
\hline
\end{tabular}




\begin{tabular}{|c|c|c|c|}
\hline \multicolumn{4}{|c|}{$\begin{array}{l}\text { Westinghouse Hanford Company } \\
\text { MILESTONE DESCRIPTION SHEET }\end{array}$} \\
\hline \multicolumn{3}{|c|}{ Title: Hanford Site Technical Baseline Rev. 6} & Date: \\
\hline \multicolumn{3}{|c|}{ Assigned To: M.L. Grygiel } & CIN: \\
\hline \multicolumn{3}{|c|}{ Program WBS Designator: 1.8 .3} & Due Date: May 1,97 \\
\hline \multicolumn{3}{|c|}{ Control Number: TSI-97-004 } & Rev: 0 \\
\hline $\begin{array}{l}\text { MILESTONE TYPE: } \\
\text { DOOE-HQ } \\
\text { [X]DOE-RL } \\
\text { _CONTRACTOR }\end{array}$ & $\begin{array}{l}\quad \text { DIVISION: } \\
\text { State } \\
\text { _Federal } \\
\text { [X] DOE } \\
\text { RCRA } \\
\text { _TPA Number }\end{array}$ & $\begin{array}{l}\text { DELIVERABLE: } \\
\text { [X]Report } \\
\text { Letter } \\
\text {-Drawings } \\
\text { _Other (specify) }\end{array}$ & $\begin{array}{l}\quad \text { ADDRESS TO: } \\
\text { _DOE-HQ } \\
\text { [X]DOE-RL } \\
\text { [X]Other (WHC } \\
\text { Programs) }\end{array}$ \\
\hline \multicolumn{4}{|c|}{$\begin{array}{l}\text { Milestone Description: The Hanford Site Technical Baseline Database provides the traceability from the } \\
\text { Hanford Mission to the Hanford Site Specification, and ultimately to the Project Multi-Year Work Plans. } \\
\text { It is the controlled source of information in the Hanford Site Specification, Super ICD Matrix, Site System } \\
\text { Analyses, and the Technical Issues Management List. It contains the relationships between the Site cleanu } \\
\text { functions, requirements, and architecture. It also provides a method for mapping the WBS elements to the } \\
\text { Technical Baseline. } \\
\text { As such it is necessary to keep the information in the HSTB as current as possible. One method for } \\
\text { accomplishing that goal is the annual update via a Project level data call. }\end{array}$} \\
\hline \multicolumn{4}{|c|}{$\begin{array}{l}\text { Description of what constitutes completion of this milestone: Issuance of the ECN that documents update } \\
\text { of the HSTB to Rev. } 6 .\end{array}$} \\
\hline \multicolumn{4}{|c|}{ Milestone Description Approval } \\
\hline \multicolumn{2}{|c|}{ Cost Account Manager Date } & \multicolumn{2}{|r|}{ Program/Project Manager Date } \\
\hline P.A. Baynes & Element Manager Date & & DOE Program Manager Date \\
\hline \multicolumn{4}{|c|}{ Milestone Completion Acceptance } \\
\hline P.A. Baynes & Element Manager Date & . & DOE Program Manager Date \\
\hline
\end{tabular}




\begin{tabular}{|c|c|c|c|}
\hline \multicolumn{4}{|c|}{$\begin{array}{l}\text { Westinghouse Hanford Company } \\
\text { MILESTONE DESCRIPTION SHEET }\end{array}$} \\
\hline \multicolumn{3}{|c|}{ Title: Hanford Site Technical Baseline Rev. 7} & Date: \\
\hline \multicolumn{3}{|c|}{ Assigned To: M.L. Grygiel } & CIN: \\
\hline \multicolumn{3}{|c|}{ Program WBS Designator: 1.8.3 } & Due Date: Sep 30,97 \\
\hline \multicolumn{3}{|c|}{ Control Number: TSI-97-005 } & Rev: 0 \\
\hline $\begin{array}{l}\text { MILESTONE TYPE: } \\
\text { DOE-HQ } \\
\text { [X]DOE-RL } \\
\text { _CONTRACTOR }\end{array}$ & $\begin{array}{l}\quad \text { DIVISION: } \\
\text { State } \\
\text {-Federal } \\
\text { [X] DOE } \\
\text { _RCRA } \\
\text { _TPA Number }\end{array}$ & $\begin{array}{l}\text { DELIVERABLE: } \\
\text { [X]Report } \\
\text { _Letter } \\
\text { _Drawings } \\
\text { _Other (specify) }\end{array}$ & $\begin{array}{l}\text { ADDRESS TO: } \\
\text { DOE-HQ } \\
\text { [X]DOE-RL } \\
\text { [X]Other (WHC } \\
\text { Programs) }\end{array}$ \\
\hline \multirow{2}{*}{\multicolumn{4}{|c|}{$\begin{array}{l}\text { Milestone Description: The Hanford Site Technical Baseline Database provides the traceability from the } \\
\text { Hanford Mission to the Hanford Site Specification, and ultimately to the Project Multi-Year Work Plans. } \\
\text { It is the controlled source of information in the Hanford Site Specification, Super ICD Matrix, Site System } \\
\text { Analyses, and the Technical Issues Management List. It contains the relationships between the Site cleanu } \\
\text { functions, requirements, and architecture. It also provides a method for mapping the WBS elements to the } \\
\text { Technical Baseline. } \\
\text { As such it is necessary to keep the information in the HSTB as current as possible. One method for } \\
\text { accomplishing that goal is the annual update via the Project level MYWP preparations. }\end{array}$}} \\
\hline & & & \\
\hline \multicolumn{4}{|c|}{$\begin{array}{l}\text { Description of what constitutes completion of this milestone: Issuance of the ECN that documents update } \\
\text { of the HSTB to Rev. } 7 \text {. }\end{array}$} \\
\hline \multicolumn{4}{|c|}{ Milestone Description Approval } \\
\hline \multicolumn{2}{|c|}{ Cost Account Manager Date } & \multicolumn{2}{|r|}{ Program/Project Manager Date } \\
\hline \multicolumn{2}{|r|}{ n Element Manager Date } & \multicolumn{2}{|r|}{ DOE Program Manager Date } \\
\hline \multicolumn{4}{|c|}{ Milestone Completion Acceptance } \\
\hline & Element Manager Date & & DOE Program Manager Date \\
\hline
\end{tabular}


4.0 COST BASELINE

4.1

$B / A$ and Cost Baseline Summaries By Year (BCWS/PMB/Life-Cycle Cost)

4.2 Basis of Estimate

4.3 Planned Staffing Profiles (Average Fu11-Time Equivalents) 
FY 97 PIANNING WORKSHEET

1.8 .3 - Sys Engr Exc \& Mgmt . Program Elenent Manager. M, Grygie1

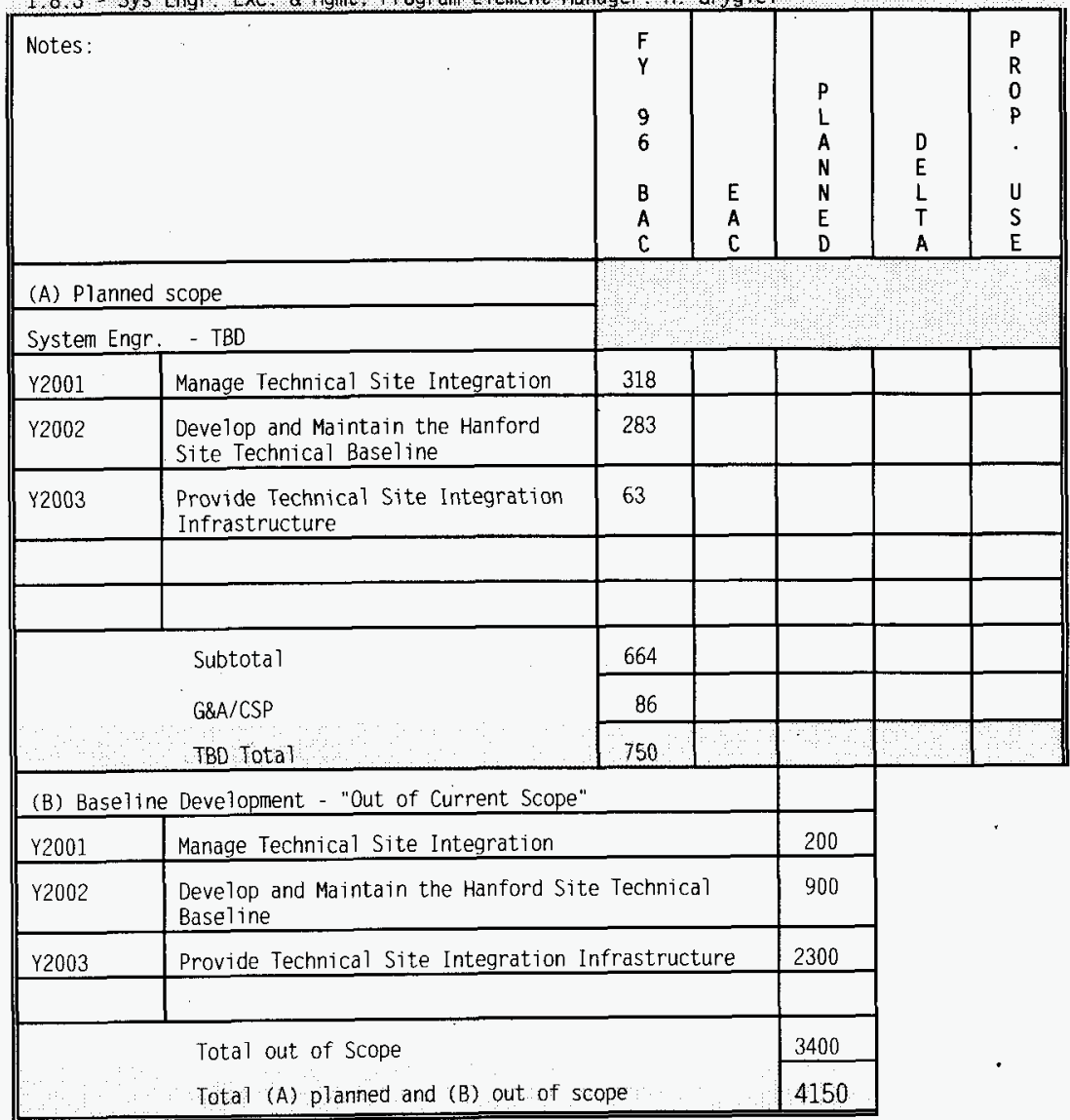


BASIS OF ESTIMATE

SITE TECHNICAL BASELINE INTEGRATION - FY 97

\begin{tabular}{|c|c|c|c|c|}
\hline No.: & TASK & $\begin{array}{c}\text { DATE } \\
\text { (Begin - End) }\end{array}$ & $\begin{array}{l}\text { WORK } \\
\text { DAYS }\end{array}$ & TEAM \\
\hline \multicolumn{5}{|c|}{ 1.8.3.1 Manage Technical Systems Integration: This element manages the Technical Integration effort: } \\
\hline \multirow[t]{4}{*}{1} & \multirow{4}{*}{$\begin{array}{l}\text { Direct the Technical Integration for the Hanford Site } \\
\text { - Support DOE interfaces with the Defense Nuclear } \\
\text { Facilities Safety Board and National Academy of } \\
\text { Sciences } \\
\text { Monitor and report on cost, schedule and technical } \\
\text { - } \quad \text { performance for WBS element } 1.8 .3 \\
\text { - Develop the annual MYWP for WBS element 1.8.3. }\end{array}$} & \multirow{4}{*}{$\begin{array}{l}\text { Oct } 1996 \\
\text { Sep } 1997\end{array}$} & 125 & Grygiel \\
\hline & & & 100 & Baynes \\
\hline & & & 125 & Bennett \\
\hline & & & 63 & Buriak \\
\hline \multirow[t]{3}{*}{2} & \multirow{3}{*}{$\begin{array}{l}\text { Site Wide System Engineering Integration Group } \\
\text { Weekly meetings } \\
\text { - agendas } \\
\text { - minutes } \\
\text { - attendance }\end{array}$} & \multirow{3}{*}{$\begin{array}{l}\text { Oct } 1996 \\
\text { Sep } 1997\end{array}$} & 25 & Bath \\
\hline & & & 25 & Baynes \\
\hline & & & 25 & Project Representatives \\
\hline \multirow[t]{3}{*}{3} & \multirow{3}{*}{$\begin{array}{l}\text { ISSUES MANAGEMENT } \\
\text { Actively manage issue generation and closeout } \\
\quad \text { - Ad HOC Teams } \\
\quad \text { - Monthly Issue Management List } \\
\text { Update the HSTB via change requests } \\
\text { Owners Resolve Issues }\end{array}$} & \multirow{3}{*}{$\begin{array}{l}\text { Oct } 1996 \\
\text { Sep } 1997\end{array}$} & 225 & Bath \\
\hline & & & 25 & Baynes \\
\hline & & & $\begin{array}{c}50 \\
+ \text { TBD }\end{array}$ & Project Representatives \\
\hline
\end{tabular}


BASIS OF ESTIMATE

SITE TECHNICAL BASELINE INTEGRATION - FY 97

\begin{tabular}{|c|c|c|c|c|}
\hline No. & TASK & $\begin{array}{c}\text { DATE } \\
\text { (Begin - End) }\end{array}$ & $\begin{array}{l}\text { WORK } \\
\text { DAYS }\end{array}$ & TEAM \\
\hline \multicolumn{5}{|c|}{$\begin{array}{l}\text { 1.8.3.2 Develop and Maintain Hanford Site Technical Baseline: This element develops and maintains the Hanford } \\
\text { Cleanup Technical Baseline (HSTB) to the level that is necessary for a site level System requirements review } \\
\text { (SRR): }\end{array}$} \\
\hline 4 & $\begin{array}{l}\text { MAINTAIN HANFORD SITE TECHNICAL BASELINE } \\
\text { Incorporate Change Requests as Submitted } \\
\text { Prepare Report Writers } \\
\text { ICD } \\
\text { Issues Management List } \\
\text { MYWP Section 1 } \\
\end{array}$ & $\begin{array}{l}\text { Oct } 1996 \\
\text { Sep } 1997\end{array}$ & 50 & Bailey \\
\hline $4 \mathrm{~b}$ & Data Call to Projects & Feb 1997 & & Bailey \\
\hline $4 c$ & Projects Provide Information & $\begin{array}{l}\text { Feb 1, } 1997 \\
\text { Feb 28, } 1997\end{array}$ & 22 & Project Representatives \\
\hline $4 d$ & Update HSTB & $\begin{array}{l}\text { Feb 1, } 1997 \\
\text { May 1, } 1997 \\
\end{array}$ & 44 & Bailey \\
\hline $4 \mathrm{e}$ & Rev. 6 HSTB & Apr 1997 & & Bajley \\
\hline $4 f$ & Update HSTB & $\begin{array}{l}\text { Aug } 1,1997 \\
\text { Sep 29, } 1997 \\
\end{array}$ & 29 & Bailey \\
\hline $4 \mathrm{~g}$ & Rev. 7 HSTB Based on MYWP Input & Sep 30, 1997 & & Bailey \\
\hline
\end{tabular}


BASIS OF ESTIMATE

SITE TECHNICAL BASELINE INTEGRATION - FY 97

\begin{tabular}{|c|c|c|c|c|}
\hline No. & TASK & $\begin{array}{c}\text { DATE } \\
\text { (Begin - End) }\end{array}$ & $\begin{array}{l}\text { WORK } \\
\text { DAYS }\end{array}$ & TEAM \\
\hline 5 & SITE SYSTEMS ANALYSES & & & \\
\hline $5 a$ & $\begin{aligned} \text { Develop Site Systems Analyses - Primary Streams } \\
\text { - Solid Waste TRU } \\
\text { - Solid Waste } \\
\text { - Spent Nuclear Fuel } \\
\text { - Transition Projects } \\
\text { - Infrastructure } \\
\text { - Liquid Effluents } \\
\text { - Environmental Restoration } \\
\end{aligned}$ & $\begin{array}{l}\text { Oct 1, } 1996 \\
\text { Jan 1. } 1997\end{array}$ & 58 & Bailey \\
\hline $5 b$ & $\begin{array}{l}\text { Project Review and Comment - Primary Streams } \\
\text { - Solid Waste TRU } \\
\text { - Solid Waste } \\
\text { - Spent Nuclear Fuel } \\
\text { - Transition Projects } \\
\text { - Infrastructure } \\
\text { - Liquid Effluents } \\
\text { - Environmental Restoration }\end{array}$ & $\begin{array}{l}\text { Feb 3. } 1997 \\
\text { Mar 7. } 1997\end{array}$ & 24 & Project Representatives \\
\hline
\end{tabular}


BASIS OF ESTIMATE

SITE TECHNICAL BASELINE INTEGRATION - FY 97

\begin{tabular}{|c|c|c|c|c|}
\hline No. & TASK & $\begin{array}{c}\text { DATE } \\
\text { (Begin - End) }\end{array}$ & $\begin{array}{l}\text { WORK } \\
\text { DAYS }\end{array}$ & TEAM \\
\hline $5 c$ & $\begin{aligned} \text { Develop Site Systems Analyses - Secondary Streams. } \\
\text { - Solid Waste } \\
\text { - Spent Nuclear Fuel } \\
\text { - Transition Projects } \\
\text { - Infrastructure } \\
\text { - Liquid Effluents } \\
\text { - Environmental Restoration } \\
\end{aligned}$ & $\begin{array}{l}\text { Apr 30, } 1997 \\
\text { Aug 1, } 1997\end{array}$ & 33 & Bailey \\
\hline $5 d$ & $\begin{aligned} \text { Project Review and Comment - Primary Streams } \\
\text { - Solid Waste } \\
\text { - Spent Nuclear Fuel } \\
\text { - Transition Projects } \\
\text { - Infrastructure } \\
\text { - Liquid Effluents } \\
\text { - Environmental Restoration } \\
\end{aligned}$ & $\begin{array}{l}\text { Aug 25, } 1997 \\
\text { Sep 26, } 1997\end{array}$ & 24 & Project Representatives \\
\hline \multirow[t]{2}{*}{6} & \multirow{2}{*}{$\begin{array}{l}\text { SITE SPECIFICATION } \\
\text { Respond to comments on Site Specification } \\
\text { Submit Site Specification to RL for review and approval }\end{array}$} & \multirow{2}{*}{$\begin{array}{ll}\text { Oct } 1, & 1996 \\
\text { May } 1, & 1997\end{array}$} & 38 & Contract \\
\hline & & & 30 & Baynes \\
\hline $6 a$ & Integrate MDD with HSTB & $\begin{array}{l}\text { Oct } 1,1996 \\
\text { Sep } 30,1997\end{array}$ & 125 & McBeath \\
\hline
\end{tabular}




\section{BASIS OF ESTIMATE}

SITE TECHNICAL BASELINE INTEGRATION - FY 97

\begin{tabular}{|c|c|c|c|c|}
\hline No. & TASK & $\begin{array}{c}\text { DATE } \\
\text { (Begin - End) }\end{array}$ & $\begin{array}{l}\text { WORK } \\
\text { DAYS }\end{array}$ & TEAM \\
\hline 7 & INTERFACE CONTROL DOCUMENTATION & $\begin{array}{ll}\text { Oct } 1, & 1996 \\
\text { Sep } 30, & 1997 \\
\end{array}$ & 63 & Lee \\
\hline $7 a$ & Input Project interface work into HSTB & $\begin{array}{l}\text { Oct } 1,1996 \\
\text { Jan } 28.1997\end{array}$ & 60 & Lee \\
\hline $7 \mathrm{~b}$ & Finalize ICD Matrix Document Format & $\begin{array}{ll}\text { Jan 28, } 1997 \\
\text { Jan 31, } 1997 \\
\end{array}$ & 3 & Lee \\
\hline $7 c$ & Output ICD Matrix Document from HSTB & Jan 31,1997 & & Lee \\
\hline \multirow[t]{2}{*}{$7 d$} & \multirow[t]{2}{*}{ Projects review and comment } & \multirow{2}{*}{$\begin{array}{ll}\text { Jan 28, } 1997 \\
\text { Feb 28, } 1997\end{array}$} & 15 & Lee \\
\hline & & & 20 & Project Representatives \\
\hline \multirow[t]{2}{*}{$7 e$} & \multirow[t]{2}{*}{ Reconcile Project Comments } & \multirow{2}{*}{$\begin{array}{l}\text { Feb 28, } 1997 \\
\text { May 1, } 1997\end{array}$} & 34 & Lee \\
\hline & & & 23 & Project Representatives \\
\hline $7 f$ & Update the HSTB with reconciled Project Interfaces & $\begin{array}{l}\text { Aug 1, } 1997 \\
\text { Sep 29. } 1997 \\
\end{array}$ & 31 & Lee \\
\hline $7 \mathrm{~g}$ & Submit ICD Matrix Document to RL for review and approval & Sep 30, 1997 & & Lee \\
\hline 8 & PREPARE PROJECT LEVEL MYWP SECTIONS 1 & 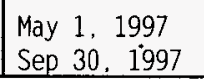 & 21 & Baynes \\
\hline
\end{tabular}


BASIS OF ESTIMATE

SITE TECHNICAL BASELINE INTEGRATION - FY 97

\begin{tabular}{|c|c|c|c|c|}
\hline No. & TASK & $\begin{array}{c}\text { DATE } \\
\text { (Begin - End) }\end{array}$ & $\begin{array}{l}\text { WORK } \\
\text { DAYS }\end{array}$ & TEAM \\
\hline $8 a$ & Prepare Section 1 of the MYWPs as directed by RL guidance & & & \\
\hline $8 b$ & Support MYWP workshops & $\begin{array}{l}\text { May 1, } 1997 \\
\text { Aug 1, } 1997 \\
\end{array}$ & 22 & Project Representatives \\
\hline \multirow[t]{2}{*}{$8 \mathrm{C}$} & \multirow{2}{*}{$\begin{aligned} \text { Gather Waste Type Data } \\
\text { - Request information } \\
\text { - Extract from BEMR and Project technical baselines } \\
\text { - Support Workshops } \\
\text { - Update HSTB via change requests } \\
\text { - Integrate data in HSTB and BEMR }\end{aligned}$} & \multirow[t]{2}{*}{$\begin{array}{l}\text { May 1, } 1997 \\
\text { Aug } 1,1997\end{array}$} & 32 & Sommer \\
\hline & & & 56 & Project Representatives \\
\hline \multirow[t]{2}{*}{$8 d$} & \multirow{2}{*}{$\begin{aligned} \text { Gather Nuclear Material Data } \\
\text { - Request information } \\
\text { - Extract from BEMR and Project technical baselines } \\
\text { - Support Workshops } \\
\text { - Update HSTB via change requests } \\
\text { - Integrate data in HSTB and BEMR }\end{aligned}$} & \multirow[t]{2}{*}{$\begin{array}{l}\text { May 1, } 1997 \\
\text { Aug 1, } 1997\end{array}$} & 32 & Sommer \\
\hline & & & 56 & Project Representatives \\
\hline \multirow[t]{2}{*}{$8 \mathrm{e}$} & \multirow{2}{*}{$\begin{aligned} \text { Gather Facilities Data } \\
\text { - Request information } \\
\text { - Extract from facility core database } \\
\text { - Support Workshops } \\
\text { - Update HSTB via change requests } \\
\text { - Integrate data in HSTB and BEMR } \\
\end{aligned}$} & \multirow[t]{2}{*}{$\begin{array}{l}\text { May } 1,1997 \\
\text { Aug } 1,1997\end{array}$} & 26 & Lee \\
\hline & & & 28 & Project Representatives \\
\hline
\end{tabular}


BASIS OF ESTIMATE

SITE TECHNICAL BASELINE INTEGRATION - FY 97

\begin{tabular}{|c|c|c|c|c|}
\hline No. & TASK & $\begin{array}{l}\text { DATE } \\
\text { (Begin - End) }\end{array}$ & $\begin{array}{l}\text { WORK } \\
\text { DAYS }\end{array}$ & TEAM \\
\hline \multirow[t]{3}{*}{$8 f$} & \multirow{3}{*}{$\begin{aligned} & \text { Gather } \text { Infrastructure Data } \\
& \text { - Request information } \\
& \text { - Support Workshops } \\
& \text { - Update HSTB via change requests } \\
& \text { - Integrate data in HSTB }\end{aligned}$} & \multirow{3}{*}{$\begin{array}{ll}\text { May } 1, & 1997 \\
\text { Aug } 1, & 1997\end{array}$} & 22 & Lee \\
\hline & & & 64 & Rinne \\
\hline & & & 56 & Project Representatives \\
\hline $8 \mathrm{~h}$ & Submit MYWP Sections 1 for approval & Sep 29, 1997 & & Bailey \\
\hline $8 i$ & Enter MYWP Data into HSTB & $\begin{array}{l}\text { May 1, } 1997 \\
\text { Aug 1, } 1997\end{array}$ & 13 & Bailey \\
\hline
\end{tabular}

1.8.3.3 Provide Hanford Site Technical Integration Infrastructure: This element provides the necessary infrastructure to enable System engineering and Systems management to be successful.

\begin{tabular}{|c|c|c|c|c|}
\hline \multirow[t]{3}{*}{9} & \multirow{3}{*}{$\begin{array}{l}\text { Administer HSTB (RDD-100) } \\
-\quad \text { Pay RDD-100 } 1 \text { icense fee } \\
-\quad \text { Upgrade to current RDD-100 version } \\
-\quad \text { Provide System backups }\end{array}$} & \multirow{3}{*}{$\begin{array}{l}\text { Oct } 1996 \\
\text { Sept } 1997\end{array}$} & 25 & Bailey \\
\hline & & & $25 \mathrm{~K}$ & Site License Fee \\
\hline & & & $25 K$ & Project License Fee \\
\hline 10 & Prepare SE Process Documents as requested & $\begin{array}{l}\text { Oct } 1996 \\
\text { Sep } 1997\end{array}$ & 50 & Baynes \\
\hline
\end{tabular}




\begin{tabular}{|c|c|c|c|c|}
\hline \multicolumn{5}{|c|}{ RESOURCE TOTALS BY MAJOR TASKS $(\$ 000)$} \\
\hline NAME & $\begin{array}{c}\text { WORK DAYS } \\
1.8 .3 .1\end{array}$ & $\begin{array}{c}\text { WORK DAYS } \\
1.8 .3 .2 \\
\end{array}$ & $\begin{array}{c}\text { WORK DAYS } \\
1.8 .3 .3 \\
\end{array}$ & $\begin{array}{c}\text { TOTAL } \\
1 \mathrm{FTE}=250\end{array}$ \\
\hline Bailey & & 225 & 25 & 250 \\
\hline Bath & 250 & & & 250 \\
\hline Baynes & 150 & 50 & 50 & 250 \\
\hline Bennett & 125 & & & 125 \\
\hline Buriak & 63 & & & 63 \\
\hline Grygie? & 125 & & & 125 \\
\hline Lee & & 250 & & 250 \\
\hline Porter & & & 63 & 63 \\
\hline TOTAL & 713 & 525 & 138 & 1376 \\
\hline TOTAL $\times \$ 504$ & $360 \mathrm{~K}$ & $265 K$ & $70 \mathrm{~K}$ & $695 \mathrm{~K}$ \\
\hline Contract Support & & 300 & $\begin{array}{c}25 K \\
(\mathrm{RDD}-100) \\
\end{array}$ & $55 \mathrm{~K}$ \\
\hline \multicolumn{5}{|c|}{ REQUIRED SUPPORT THAT IS FUNDED BY OTHER SOURCES } \\
\hline McBeath & & 125 & & 125 \\
\hline Project Representatives & $\begin{array}{c}75 \\
+\mathrm{TBD} \\
\end{array}$ & 331 & & $\begin{array}{r}406 \\
+ \text { TBD } \\
\end{array}$ \\
\hline Rinne & & 125 & & 125 \\
\hline Sommer & & 125 & & 125 \\
\hline TOTAL & & & & $\begin{array}{r}781 \\
+\mathrm{TBD} \\
\end{array}$ \\
\hline
\end{tabular}


Exhibit: Program Average FTE Projections by cocs Categories

Program WBS $\pi$ itle

1.8.3 SITEWIDE SYSTEM ENGINEERING

\begin{tabular}{|c|c|c|c|c|c|c|c|c|c|c|c|}
\hline $\operatorname{cocs}$ & Title & FY 1997 & FY 1998 & FY 1999 & FY 2000 & FY 2001 & FY 2002 & FY 2003 & FY 2004 & FY 2005 & FY 2006 \\
\hline $\mathrm{COOO}$ & Crafts & & & & & & & & & & \\
\hline$C 010$ & Carpenters & & & & & & & & & & \\
\hline $\mathrm{CO} 20$ & Electricians & & & & & & & & & & \\
\hline $\mathrm{Co30}$ & Heating Air-Conditioning and Refrig Mechanics (HVAC) & & & & & & & & & & \\
\hline $\mathrm{CO40}$ & Machinists & & & & & & & & & & \\
\hline $\mathrm{C050}$ & Masons & & & & & & & & & & \\
\hline CO60 & Millwrights & & & & & & & & & & \\
\hline $\mathrm{CO} 0$ & Painters & & & & & & & & & & \\
\hline Coso & Plumbers and Pipefitters & & & & & & & & & & \\
\hline $\operatorname{coso}$ & Structural and Metal Workers & & & & & & & & & & \\
\hline C100 & Vehicle and Mobile Equipment Mechanics & & & & & & & & & & \\
\hline $\mathrm{C} 110$ & Welders & & & & & & & & & & \\
\hline C120 & Other Crafts & & & & & & & & & & \\
\hline E000 & Engineers & & & & & & & & & & \\
\hline E010 & Chemical Engineers & & & & & & & & & & \\
\hline E020 & Civil Engineers & & & & & & & & & & \\
\hline E040 & Electrical Engineers & & & & & & & & & & \\
\hline E050 & Environmental Engineers & & & & & & & & & & \\
\hline E060 & Industrial Engineers & & & & & & & & & & \\
\hline E070 & Mechanical Engineers & & & & & & & & & & \\
\hline E080 & Nuclear Engineers & & & & & & & & & & \\
\hline E090 & Petroleum/Mining Engineers & & & & & & & & & & \\
\hline E100 & Plant Engineers & & & & & & & & & & \\
\hline E110 & Quality Assurance/Control Engineers & & & & & & & & & & \\
\hline E120 & Safety Engineers & & & & & & & & & & \\
\hline E130 & Other Engineers & 4.5 & 4.5 & 4.5 & 4.5 & 4.5 & 4.5 & 4.5 & 4.5 & 4.5 & 4.5 \\
\hline E140 & Construction Engineers & & & & & & & & & & \\
\hline 6000 & General Admin, Secretarial \& Clerical Support & & & & & & & & & & \\
\hline G010 & Administrative Assistants & & & & & & & & & & \\
\hline G020 & Office Clerks (General) & & & & & & & & & & \\
\hline G030 & Office Clerks (Specialized) & & & & & & & & & & \\
\hline G040 & Secretaries & 0.5 & 0.5 & 0.5 & 0.5 & 0.5 & 0.5 & 0.5 & 0.5 & 0.5 & 0.5 \\
\hline G050 & Typist and Word Processors. & & & & & . & & & & & \\
\hline G060 & Other General Admin, Secretarial and Clerical Support & & & & & & & & & & \\
\hline LOOO & Laborers and General Service Workers & & & & & & & & & & 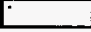 \\
\hline L010 & Firefighters & & & & & & & & & & \\
\hline L020 & Food Service Workers & & & & & & & . & & & \\
\hline L030 & Janitors and Cleaners & & & & & & & & & & \\
\hline
\end{tabular}

E060 Industrial Engineers

E070 Mechanical Engineers

E080 Nuclear Engineers

E090 Petroleum/Mining Engineers

E100 Plant Engineers

Quality Assuran Engineers

Other Engineers

onstruction Engineers

Office Clerks (Specialized)

Typist and Word Processors

Firefighters

Janitors and Cleaners 
Laundry Workers

L050 Handlers, Helpers and Laborers (General)

L060 Handlers, Helpers and Laborers (Specialized)

L070 Light Vehicle Drivers

L080 Security Guards

L090 Other Laborers and General Services Workers

Mooo

M010

M020

$\mathrm{MO30}$

M040

P000

P010

$\mathrm{P} 020$

P030

P040

P050

P060

P070

P080

i P090

芯 P100

P110

P120

P130

P140

P150

P160

P170

R000

R010

R020

R030

R040

R050

R060

R070

R080

So00

S010

S020
Gen Mgrs, Exec, 1st Line Suprv'sr \& Prog/Proj Mgrs

First Line Supervisors

General Managers and Executives

Project and Program Managers

Other Managers

Professional Administrative \& Related Occupations Accountants and Auditors

Architects

Buyers, Procurement and Contracting Specialists

Communications Specialists

Compliance Inspectors

Computer Systems Anaiysts

Cost Estimators and Planners and Schedulers

Health Physicists

Industrial Hygienists

Lawyers

Personnel and Labor Relations Specialists

Physicians

Physician Assist, Nurses \& Oth Medical Supt Occup'tns

Safeguards and Other Security Specialists

Trainers

Technical Writers, and Editors

Other Administrative \& Professional Other Occupations

\section{Operators}

Chemical System Operators

Drillers

Material Moving Equipment Operators

Nuclear Plant Operators

Nuclear Waste Process Operators

Production Systems Operators

Utilities Operators

Other Operators

Scientists

Chemists

Environmental Scientists
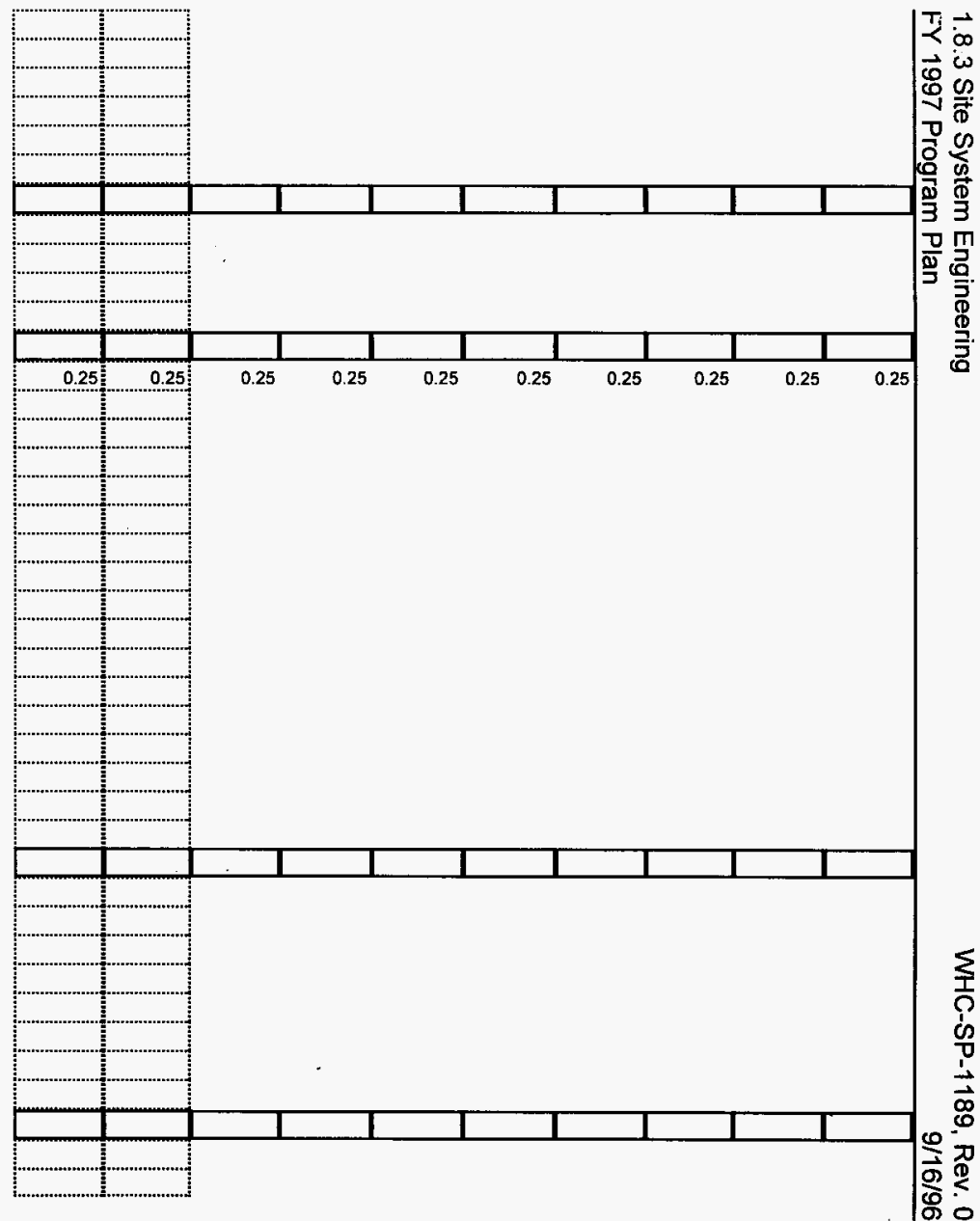


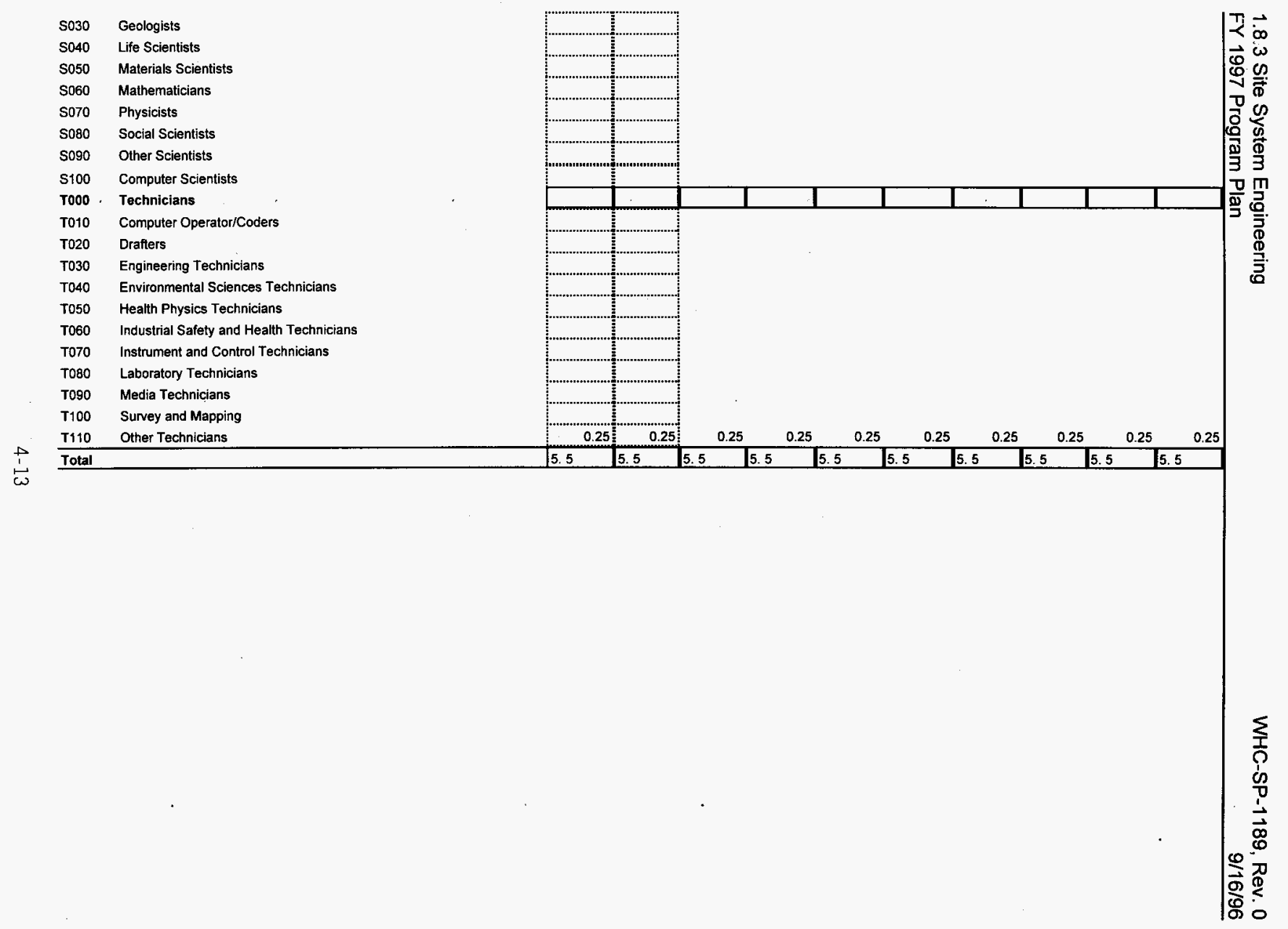




\section{Subcontractor Exhibit}

Dollars In Thousands

Project Hanford Breakdown Structure:

Project Hanford Title:

1.8.3 SITEWIDE SYSTEM ENGINEERING

FY 1997

S FTE

Expense

Service Agreement

Technical Service

Clerical

Construction

Total

\begin{tabular}{ccc} 
& $\$ 0$ & 0 \\
\hline$\$ 50 \mathrm{~K}$ & & 2 \\
\hline & $\$ 0$ & 0 \\
\hline
\end{tabular}

so

0

$\$ 50 \mathrm{k}$

$\stackrel{\overrightarrow{1}}{\stackrel{5}{D}}$

Definitions:

Subcontractor is any Hanford Site subcontractor to WHC, ICF KH, BCSR, PNNL, or BHI.

Dollars in Thousands: The base cost of the subcontract, excluding adders (procurement and G\&A).

Service Agreement subcontracts obtain special knowledge or skills, typically not materials.

Technical Service subcontracts are primarily offsite and of a highly speclalized nature.

Clerical subcontracts are for clerical support.

Construction subcontracts support capital efforts. 
EXECUTION YEAR

5.1

5.2

5.3

5.4

5.5

5.6

Performance Measure, Objectives, Measures, and Expectations Program Performance Baseline Schedule Cost Baseline by Month Cost Element by Year

Program Funding

Project Work Scope Mapping

(See 3.1 for Master Program Baseline Schedule) 


\subsection{Performance Measures}

This section identifies the Performance Measures and deliverables.

- $\quad$ Publish Monthly Issues Mangement List by the 15th of each month.

- Issue Project MYWP Section 1, consistent with the Integrated Site Baseline on September 29. 1997.

- $\quad$ Publish Super ICD Matrix Draft for approval by September 29.1997.

- Issue Hanford Site Technical Baseline, Rev 6 by May 1. (This supports issuing the Integrated Site Baseline by July 31, 1997.)

- Issue Hanford Site Technical Baseline, Rev 7 by September 30, 1997. 
EXHIBIT 1

\section{BUDGET AUTHORITY SUMMARY BY YEAR BY ADS}

(\$000s)

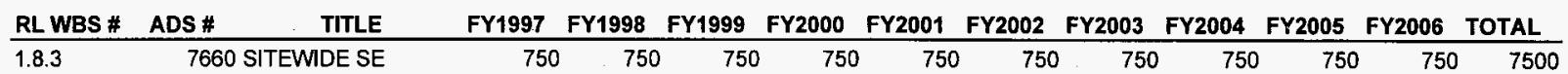


EXHIBIT 2

\section{BUDGET AUTHORITY BY YEAR BY ADS}

$(\$ 000$ s)

RL WBS \# ADS \# TITLE $\quad$ FUND TYPE FY FY FY FY FY FY FY FY FY FY TOTAL 1997199819992000200120022003200420052006

\begin{tabular}{|c|c|c|c|c|c|c|c|c|c|c|c|c|}
\hline \multirow[t]{6}{*}{1.8 .3} & $\begin{array}{l}\text { SITE } \\
\text { ENG }\end{array}$ & Systems Expense & 750 & 750 & 750 & 750 & 750 & 750 & 750 & 750 & 750750 & 7500 \\
\hline & & CENRTC & & & & & & & & & & \\
\hline & & Line Item & & & & & & & & & & \\
\hline & & GPP & & & & & & & & & & \\
\hline & & $\begin{array}{l}\text { Subtotal New } \\
B / A\end{array}$ & 750 & 750 & 750 & 750 & 750 & 750 & 750 & 750 & 750750 & 7500 \\
\hline & & $\begin{array}{l}\text { Exp e n s e } \\
\text { Carryover (1) }\end{array}$ & & & & & & & & & & \\
\hline & & Total B/A & 750 & 750 & 750 & 750 & 750 & 750 & 750 & 750 & 750750 & 7500 \\
\hline
\end{tabular}

PROGRAM NEW 7500

B/A

PROGRAM EXPENSE CARRYOVER

7500

B/A

f(1) Includes Only Expense Carryover Approved By Site Management Board (SMB) Prior To

$10 / 1 / 96$. 
EXHIBIT 3

\section{COST BASELINE BY YEAR BY ADS}

(\$000s)

\begin{tabular}{|c|c|c|c|c|c|c|c|c|c|c|c|c|c|c|}
\hline$\underset{\#}{\text { RL WBS }}$ & $\begin{array}{c}\text { ADS } \\
\#\end{array}$ & TITLE & FUND TYPE & $\begin{array}{l}\text { FY } \\
1997\end{array}$ & $\begin{array}{l}\text { FY } \\
1998 \\
\end{array}$ & $\begin{array}{l}\text { FY } \\
1999\end{array}$ & $\begin{array}{l}\text { FY } \\
2000\end{array}$ & $\begin{array}{l}\text { FY } \\
2001\end{array}$ & $\begin{array}{l}\text { FY } \\
2002 \\
\end{array}$ & $\begin{array}{l}\text { FY } \\
2003\end{array}$ & $\begin{array}{l}\text { FY } \\
2004\end{array}$ & $\begin{array}{l}\text { FY } \\
2005 \\
\end{array}$ & $\begin{array}{l}\text { FY } \\
2006\end{array}$ & TOTAL \\
\hline \multirow[t]{9}{*}{1.8 .3} & & SITE System SE & Expense & 750 & 750 & 750 & 750 & 750 & 750 & 750 & 750 & 750 & 750 & 7500 \\
\hline & & & CENRTC & & & & & & & & & & & \\
\hline & & & Line Item & & & & & & & & & & & \\
\hline & & & GPP & & & & & & & & & & & \\
\hline & & & Total BCWS/PMB (1) & 750 & 750 & 750 & 750 & 750 & 750 & 750 & 750 & 750 & 750 & 7500 \\
\hline & & & Mgmt Reserve (2) & & & & & & & & & & & \\
\hline & & & $\begin{array}{l}\text { Line Item Contingency } \\
\text { (2) }\end{array}$ & & & & & & & & & & & \\
\hline & & & $\begin{array}{l}\text { Expected Carryover } \\
\text { (3) }\end{array}$ & & & & & & & & & & & \\
\hline & & & TOTAL & 750 & 750 & 750 & 750 & 750 & 750 & 750 & 750 & 750 & 750 & 7500 \\
\hline
\end{tabular}

\begin{tabular}{ll}
\hline PRO G R A M & 7500 \\
BCWS/PMB & \\
\hline PRO G R A M & 7500 \\
TOTAL & \\
\hline
\end{tabular}

(1) Budgeted Cost Of Work Scheduled (BCWS) Equals Performance Measurement Baseline (PMB).

(2) Management Reserve And Line Item Contingency Held By RL.

(3) Includes Expected Expense Carryover Requested By Formal Change Control In FY1997. 
XHIBIT 4

COST BASELINE FOR EXECUTION YEAR

BY PROGRAM BY FUND TYPE BY MONTH

(\$000s)

L WBS PROGRAM TITLE FUND TYPE OCT NOV DEC JAN FEB MAR APR MAY JUN JUL AUg SEP TOTAL \begin{tabular}{ll}
$\#$ & \\
\hline 8.3 & Sitewide System Eng
\end{tabular}

Expense
CENRTC
Line Item
GPP

(1)

$\begin{array}{llllllllllll}54.8 & 57.5 & 54.2 & 47.4 & 67 & 49.5 & 51.1 & 62.1 & 78.2 & 62.9 & 55 & 750.4\end{array}$

Mgmt Reserve (2)

Line Item Contingency

(2)

E $\times$ p e c t e d

Carryover (3)

$\begin{array}{llllllllllllll}\text { TOTAL } & 110.9 & 54.8 & 57.5 & 54.2 & 47.4 & 67 & 49.5 & 51.1 & 62.1 & 78.2 & 62.9 & 55 & 750.4\end{array}$


EXHIBIT 5

\section{COST BASELINE FOR EXECUTION YEAR BY PROGRAM BY COST ELEMENT BY MONTH}

\begin{tabular}{|c|c|c|c|c|c|c|c|c|c|c|c|c|c|c|c|}
\hline \multirow[b]{2}{*}{ RL WBS \# } & \multicolumn{10}{|c|}{ (\$000s) } & \multirow[b]{2}{*}{ JUN } & \multirow[b]{2}{*}{ JUL } & & \multirow[b]{2}{*}{ SEP } & \multirow[b]{2}{*}{ TOTAL } \\
\hline & PROGRAM TITLE & COST ELEMENT & OCT & NOV & DEC . & JAN & FEB & MAR & APR & MAY & & & AUG & & \\
\hline \multirow[t]{10}{*}{1.8 .3} & Sitewide System Eng & 0 Salaries \& Cont of Serv & 31.3 & 32.8 & 34.4 & 32.4 & 28.4 & 40.1 & 29.6 & 33.1 & 37.1 & 26.3 & 37.6 & 32.9 & 393.7 \\
\hline & & 1 Material & & & & & & & & & & 25 & & & 25 \\
\hline & & 2 Purchased Services & 48 & & & & & & & & & & & & 48 \\
\hline & & 3 Charges From Other Contr & & & & & & & & & & & & & \\
\hline & & 4 Internal Services & 2.5 & & & & & & & & & 4.5 & & & 7 \\
\hline & & 5 Internal Charges & & & & & & & & & & & . & & \\
\hline & & 6 BCS Richland & & & & & & & & & & & & & \\
\hline & & 7 Overheads \& Adders & 29.1 & 22 & 23 & 21.8 & 19 & 26.8 & 19.8 & 20.5 & 25 & 22.4 & 25.3 & \multirow{2}{*}{\multicolumn{2}{|c|}{22.1276 .7}} \\
\hline & & 8 Revenue & & & & & & & & & & & & & \\
\hline & & Total BCWS/PMB (1) & 110.9 & 54.8 & 57.4 & 54.2 & 47.4 & 66.9 & 49.4 & 53.6 & 62.1 & 78.2 & 62.9 & \multicolumn{2}{|c|}{55750.4} \\
\hline
\end{tabular}

PROGRAM BCWS/PMB

750.4

(1) Budgeted Cost Of Work Scheduled (BCWS) Equals Performance Measurement Baseline (PMB) And Is Consistent With BCWS/PMB (Exhibit 3).

Above Amounts Do NOT Include Management Reserve Held By RL, Line Item Contingency Held By RL, Or Expected Expense Carryover Requested By Formal Change Control In FY1997. 


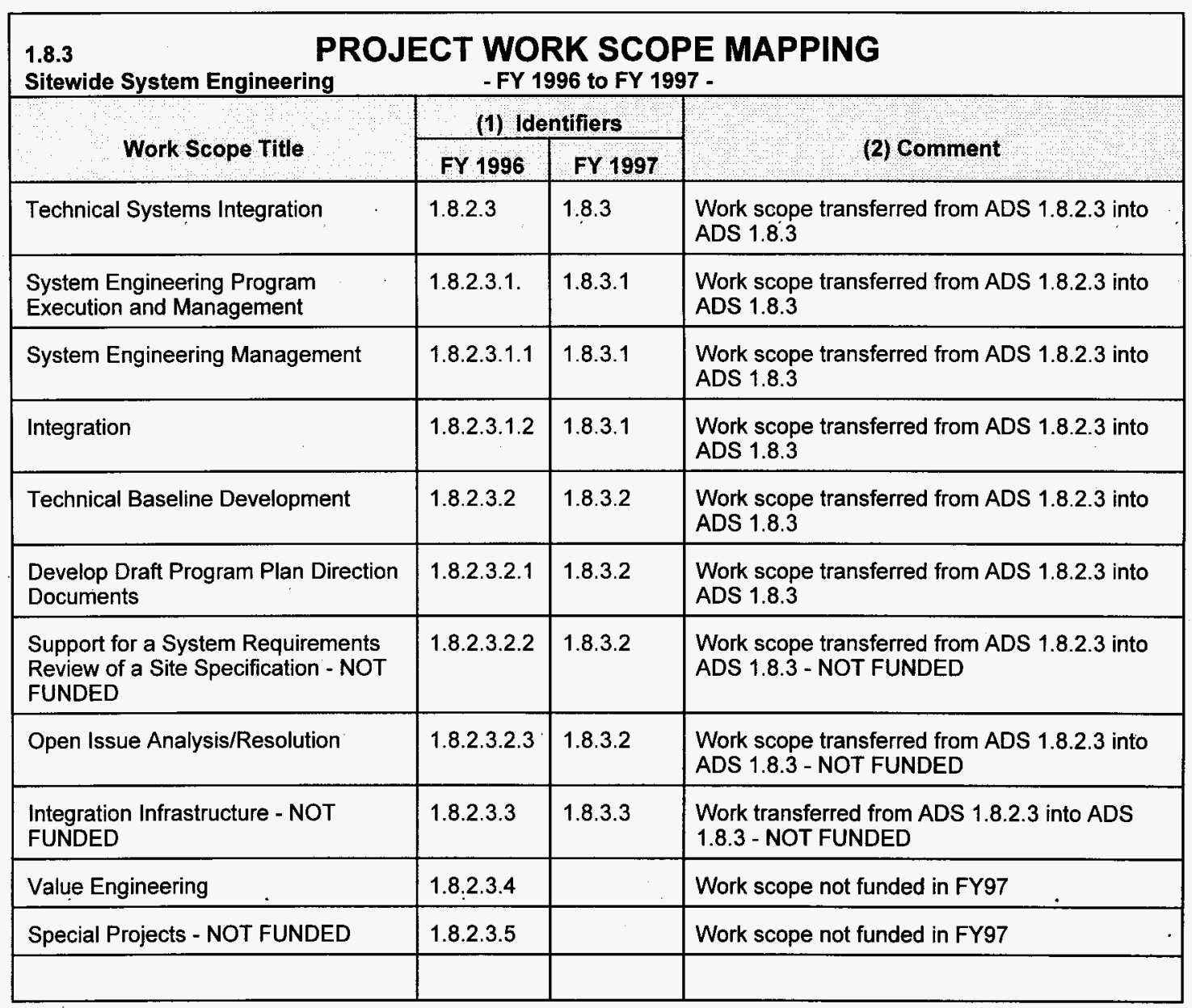


CA/MBS: 1YZ3A1 SYS ENGR PROG EXEC \& MGMT CA Manager: GRYGIEL, ML

Resp Org: 02000 HANFCRD SYSTEMS INTEGRATION GL Index: RBA B \& R Number: EUB110010 \& \& R Title: PROGRAM CONTROL/SUPPORT
Funding Source: 1997 EXPENSE CAP Orig Date : 07/28/95

Budget Analyst: A2 - HOLMES, JE
WORK PACKAGE: 1YZ3AI10 MANACE TECHNICAL SYSTEMS INIEG ScOpe of WOrk: Resp Org:
02100 SITE TECHNICAL INTEGRATION
MANACE TECHNICAL SYSTEMS INTEGRATION

\section{Cep Rev: 00 Cin: $\quad$ Start Completion Budget (K\$): 750.0 Date Date} Phone: 376-200310/01/96 09/30/96 CAP STATUS: $D$

\begin{tabular}{|c|c|c|}
\hline $\begin{array}{l}\text { Task: IY23A11001 Y1831 MANACE TECH SYS INTEGRATION } \\
\text { Responsible Org: } 02100 \text { SITE TECHNICAL INTEGRATION } \\
\text { E V Method: } 4 \text { LEVEL OF EFFORT METHOO } \\
\text { Parent WBS: }\end{array}$ & $\begin{array}{l}\text { Scope of Work: } \\
\text { MANACE TECHNICAL SYSTEMS INTEGRATION }\end{array}$ & $\begin{array}{l}\text { Revision No: } 00 \\
\text { Date: } 07 / 31 / 96 \\
\text { Cin Num: } \\
\text { CAP STATUS: D }\end{array}$ \\
\hline
\end{tabular}

Fiscal Year: 1997

Performing Org: 02100 SITE TECHNICAL INTEGRATION Approved By: GRYGIEL, ML

\begin{tabular}{|c|c|c|c|c|c|c|c|c|c|c|c|c|c|c|}
\hline \multicolumn{2}{|l|}{ Cost Elements: } & oct & Nov & Dec & Jan & Fetb & Mar & Apr & May & Jun & Jul & Alg & Sep & Iotal \\
\hline \multicolumn{2}{|c|}{ Staff } & 0.5 & 0.5 & 0.5 & 0.5 & 0.5 & 0.5 & 0.5 & 0.5 & 0.5 & 0.5 & 0.5 & 0.5 & 0.5 \\
\hline \multirow{3}{*}{ OO NON-EX LABOR } & R Hrs & 70 & 73 & $\pi 7$ & 70 & 71 & 93 & 73 & 72 & 88 & 62 & 87 & 76 & 912 \\
\hline & $\$$ & 1.5 & 1.6 & 1.7 & 1.5 & 1.5 & 2.0 & 1.6 & 1.6 & 1.9 & 1.3 & 1.9 & 1.6 & 19.7 \\
\hline & Staff & 2.4 & 2.4 & 2.4 & 2.4 & 2.4 & 2.4 & 2.4 & 2.4 & 2.4 & 2.4 & 2.4 & 2.4 & 2.4 \\
\hline \multirow[t]{2}{*}{01 EXEMPT LABOR } & Hrs & 334 & 350 & 367 & 334 & 341 & 444 & 348 & 346 & 420 & 298 & 418 & 365 & 4365 \\
\hline & $\$$ & 13.9 & 14.5 & 15.2 & 13.9 & 14.1 & 18.4 & 14.4 & 14.4 & 17.4 & 12.4 & 17.3 & 15.1 & 181.1 \\
\hline \multicolumn{2}{|l|}{ 7C ORG OVERHEAD } & 6.8 & 7.1 & 7.4 & 6.8 & 6.9 & 9.0 & 7.0 & 7.0 & 8.5 & 6.0 & 8.5 & 7.4 & 88.3 \\
\hline \multirow[t]{3}{*}{ Total BCWS } & Staff & 2.9 & 2.9 & 2.9 & 2.9 & 2.9 & 2.9 & 2.9 & 2.9 & 2.9 & 2.9 & 2.9 & 2.9 & 2.9 \\
\hline & Hirs & 404 & 423 & 444 & 404 & 412 & 537 & 421 & 418 & 508 & 360 & 505 & 441 & 5277 \\
\hline & $\$$ & 22.1 & 23.2 & 24.3 & 22.1 & 22.6 & 29.4 & 23.1 & 22.9 & 27.8 & 19.7 & 27.7 & 24.2 & 289.1 \\
\hline
\end{tabular}

Total BCWP:

WORK PACKAGE: TYZ3A120 DEV \& MAINT. HSTB Resp Org:
02100 SITE TECHNICAL INTEGRATION
Scope of Work:

DEVELOP AND MAINTAIN haNFORD SIIE TECHNICAL BASELINE
Revision No: 00

Date: $07 / 31 / 96$

\section{CAP STATUS: D}

Cin Num:

ATUS: 


\begin{tabular}{|c|c|c|c|c|c|c|c|c|c|c|c|c|c|c|}
\hline \multirow[t]{2}{*}{01 EXEMPI LABOR } & Hrs & 320 & 336 & 352 & 348 & 241 & 389 & 261 & 288 & 350 & 248 & 365 & 319 & 3817 \\
\hline & $\$$ & 13.3 & 13.9 & 14.6 & 14.4 & 10.0 & 16.1 & 10.8 & 12.0 & 14.5 & 10.3 & 15.1 & 13.2 & 158.4 \\
\hline 21 PO CONTRACTS & $\$$ & 48.0 & 0.0 & 0.0 & 0.0 & 0.0 & 0.0 & 0.0 & 0.0 & 0.0 & 0.0 & 0.0 & 0.0 & 48 \\
\hline $4 C \mathrm{MPR}$ & $\$$ & 2.5 & 0.0 & 0.0 & 0.0 & 0.0 & 0.0 & 0.0 & 0.0 & 0.0 & 0.0 & 0.0 & 0.0 & \\
\hline 7C ORG OVERHEAD & & 5.8 & 6.1 & 6.4 & 6.4 & 4.4 & 7.1 & 4.8 & 5.3 & 6.4 & 4.5 & 6.7 & 5.8 & 69 \\
\hline Total BCus & Staff & 2.3 & 2.3 & 2.3 & 2.5 & 1.7 & 2.1 & 1.8 & 2.0 & 2.0 & 2.0 & 2.1 & 2.1 & \\
\hline & Hrs & 320 & 336 & 352 & 348 & 241 & 389 & 261 & 288 & 350 & 248 & 365 & 319 & 3817 \\
\hline & $\mathbf{5}$ & 69.6 & 20.1 & 21.0 & 20.8 & 14.4 & 23.2 & 15.6 & 17.2 & 20.9 & 14.8 & 21.8 & 19.1 & \\
\hline
\end{tabular}

Total BCWP:

\section{WORK PACXAGE: 1Y23A130 SITE TECH INTEG INFRASTRUCTURE Resp Org: \\ 02100 SITE TECHNICAL INTEGRATION}

Scope of Work:

PROVIOE HANFORD SITE TECHNICAL INTEGRATION INFRASTRUCTURE
Revision No: 00

Date: $07 / 31 / \%$

CAP STATUS: D

\section{Task: IY23A13001 Y1833 SITE TECH INTEGR INFRASTURCTUR Scope of Work: \\ Responsible Org: 02100 SIIE TECHNICAL INTEGRATION \\ E V Method: 4 LEVEL OF EFFORT METHOO \\ PROVIOE HANFORD SITE TECHNICAL INTEGRATION \\ INFRASTRUCTURE}

Revision No: 00

Date: $07 / 31 / 96$

Cin Num:

CAP STATUS: D

Fiscal Year: 1997

Performing Org: 02100 SITE TECHNICAL INTEgRATION

Approved By: GRYGIEL, ML

Cost Elements:

oct Nov Dec

$\operatorname{Jan}$

Feb

2-2983 Date: $/ /$

OO NON-EX LABOR HTS

taff

$\begin{array}{llll}0.3 & 0.3 & 0.3 & 0.3\end{array}$

0.3

0.3

Mar

Apr

May

Jun Jul

Aug

Sep Total

$\$$

0.9

$\begin{array}{rr}44 & 46 \\ 0.9 & 1.0\end{array}$

42
0.9

0.3

0.3

0.3

0.3

0.3

$\begin{array}{lll}0.3 & 0.3 & 0.3\end{array}$

Staff

0.3

$0.3 \quad 0.3$

0.9

1.2

0.9

0.9

1.1

37
0.8

52

$46 \quad 548$

01 EXEMPT LABOR Hrs

$\begin{array}{rrrr}0.3 & 0.3 & 0.3 & 0.3 \\ 42 & 44 & 46 & 42 \\ 1.7 & 1.8 & 1.9 & 1.7\end{array}$

0.30 .3

0.30 .3

0.30 .3

0.30 .3

30

$\$$

19

19 COMPUTER-HAR

re

TC CRG OVERHEAD

$\begin{array}{llll}0.0 & 0.0 & 0.0 & 0\end{array}$

$\begin{array}{rr}42 & 43 \\ 7 & 1.8\end{array}$

$\begin{array}{rr}56 & 44 \\ 2.3 & 1.8\end{array}$

1.8

53

0.30 .3

$0.3 \quad 0.3$

0.3

Total BCWS Staff

\begin{tabular}{|c|c|c|c|c|c|c|c|c|c|c|c|c|c|}
\hline Staff & 0.6 & 0.6 & 0.6 & 0.6 & 0.6 & 0.6 & 0.6 & 0.6 & 0.6 & 0.6 & 0.6 & 0.6 & 0.6 \\
\hline $\mathrm{Hrs}$ & 84 & 88 & 92 & 84 & 86 & 112 & 88 & 86 & 106 & 74 & 104 & 92 & $10 \% 6$ \\
\hline$\$$ & 3.8 & 4.0 & 4.2 & 3.8 & 3.9 & 5.1 & 4.0 & 3.9 & 4.8 & 32.9 & 4.7 & 4.2 & 79.3 \\
\hline
\end{tabular}

Total BCWP:

Total CAP

Oct Nov Dec Jan Feb Mar Apr May Jun Jul Aug Sep Total Staff $\begin{array}{llll}0.8 & 0.8 & 0.8 & 0.8\end{array}$

$0.8 \quad 0.8$

$8 \quad 0.8$

$.8 \quad 0.8$

$0.8 \quad 0.8$

$0.8 \quad 0.8$

$\begin{array}{llll}0.8 & 0.8 & 0.8 & 0.8\end{array}$ 


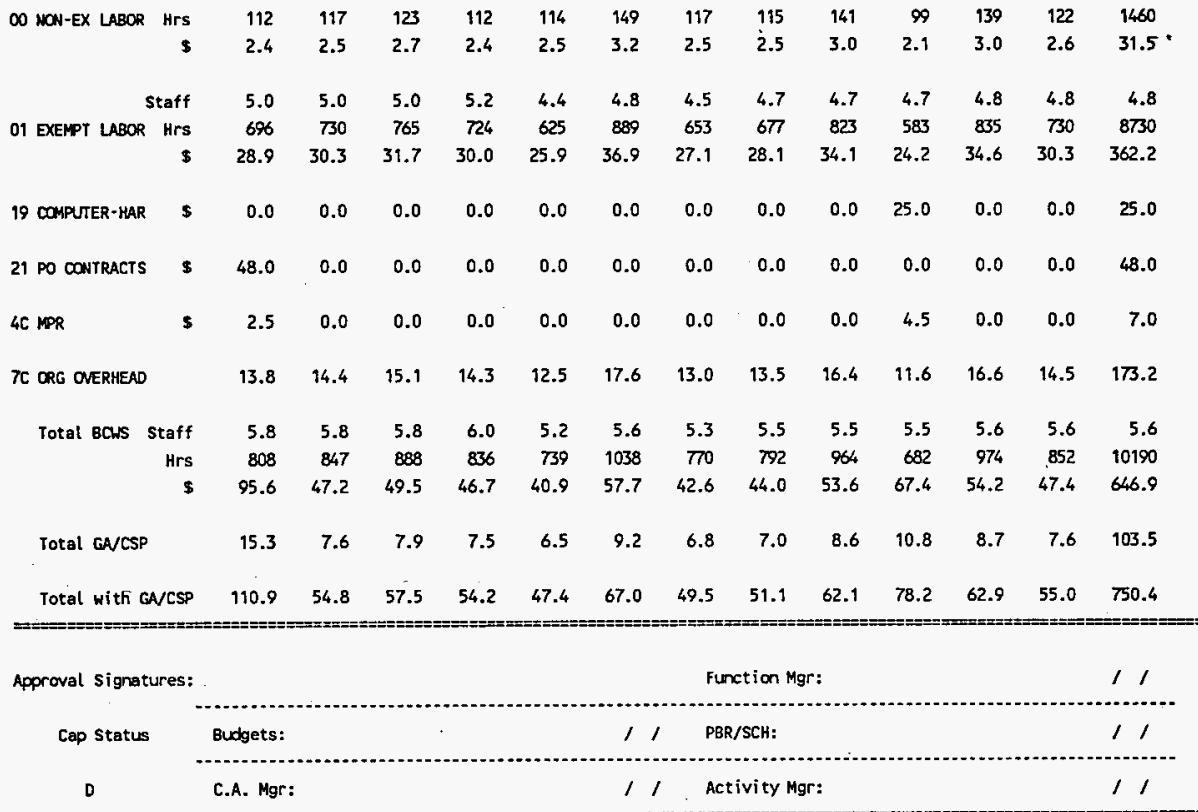

